\title{
Mega, February 1941: The role of the 1st South African Irish Regiment
}

\author{
Dr S. Monick \& Cmdt O.E.F. Baker, DWD*
}

\section{Introduction}

Dr S. Monick and Cmdt O.E.F. Baker, DWD are at present engaged in compiling the work, entitled Clear the way: the military heritage of the South African Irish 1880-1990 (scheduled for publication in mid-1991). As the title implies, the study embraces the contribution of the South African Irish community to South Africa's military heritage, spanning over a century. The main body of the book details the regimental history of the 1st South African Irish Regiment, which has formed the conduit, or channel, of that contribution since 1939. The Regiment was originally conceived as a war service battalion (as was its predecessor in World War I) and officially instituted on 1 November 1939. As is well known, its service in World War II encompassed Abyssinia (January-February 1941) and North Africa; culminating in the Battle of Sidi Rezegh (23 November 1941), which effectively destroyed 5 SA Infantry Brigade and, as a consequence, spelt the demise of the South African Irish Regiment for the remainder of World War II.

It is considered apposite to present the reader with a small, but highly significant, section of the forthcoming publication; viz that relating to the Battle of Mega (15-18 February 1941). The year 1991 marks the 50th anniversary of this struggle; as well as that of the Battle of Sidi Rezegh. However, whilst the latter has been exhaustively treated in published works (on virtually an annual basis, with regard to newspapers and periodicals), Mega has received, in contrast, comparatively little attention. Yet the battle forms an important historical landmark in the collective psychology of the Regiment - an essential component in the formation of traditions based on shared experiences - which, it is hoped, will become apparent in the course of this article.

The following study is patterned on the basis of those central determinants which, it is considered by the authors, mould the history of a specific regiment; viz the organizational framework within which it is contained; the character of the leadership echelon; and the configuration and central features of the campaign in which it is involved. The first aspect - the larger military formation (ie. Brigade, Division) of which it forms a component - shapes the movements of the Battalion, and determines the theatres of war in which it is involved. The second facet - the impress of its leadership cadre - determines its moral health, so to speak (eg. morale, professional calibre, sense of identity, response to challenges, etc.). The third characteristic - the strategic/tactical configuration of the campaign - shapes the tempo and atmosphere of the combat scenario.

\section{THE ORGANIZATIONAL FRAMEWORK}

At the outset, it is necessary to place the 1st South African Irish Regiment within its organizational framework, or its allocated place within the Order of Battle.

In October the news was received that the Regiment was to form a component of 5 Brigade within 1 SA Infantry Division [ 1 SA Infantry Division comprised 1, 2 and 5 SA Infantry Brigades. The Division had originally been formed on 13 August 1940, its nucleus consisting of these respective brigade groups; each, in turn, composed of the following regiments:

1 SA Infantry Brigade (Brig (later Maj Gen) D.H. Pienaar)

1 Bn Royal Natal Carbineers (Lt Col L. Hay)

1 Bn Duke of Edinburgh's Own Rifles (Lt Col G.T. Seneschall)

1 Bn Transvaal Scottish (Lt Col D.F. Smitheman; later Lt Col E.P. Hartshorn)

\section{SA Infantry Brigade (Brig F.L.A. Buchanan)}

1 Bn Natal Mounted Rifles (Lt Col N.D. McMillan) Field Force Brigade

$1 \mathrm{Bn}$ (Lt Col H.P. van Noorden)

$2 \mathrm{Bn}$ (Lt Col C.L. Engelbrecht)

[In June 1941 amalgamated into Field Force Battalion; commanded successively by: Lt Col Engelbrecht, Lt Col Olsen and Lt Col (later Brig) J.B. Bester.]

\section{SA Infantry Brigade (Brig B.F. Armstrong)}

1 SA Irish Regiment (Lt Col J. Moreland; succeeded by Lt Col D.I. Somerset; succeeded by Lt Col J.F.K. Dobbs) 
3 Bn Transvaal Scottish (Lt Col W. Kirby) 2 Regt Botha (Lt Col J.C. du Preez) ]

The divisional commander was Maj Gen (later Lt Gen) G.E. Brink and the Brigade Commander Brig B.F. Armstrong.

After 7 November the Regiment was sent on embarkation leave. The Battalion left Durban on the afternoon of 21 November for Mombasa, sailing on the Llanstephen Castle.

\section{LEADING PERSONALITIES IN OFFICER ESTABLISHMENT}

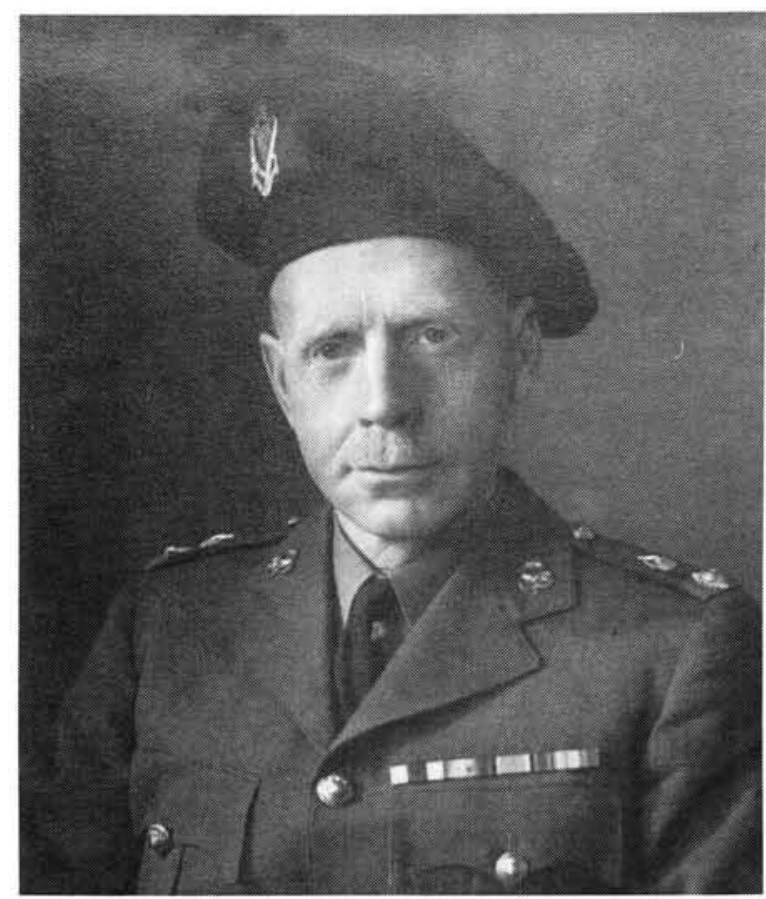

Lt Col J.F.K. Dobbs M.C.

\section{Maj (later Lt Col) J.F.K. Dobbs, MC (1888-1956)}

Maj (later Lt Col) J.F.K. Dobbs, MC, played a major role in the subsequent history of the Regiment, commanding the Battalion in Abyssinia and in North Africa, culminating at Sidi Rezegh, at which fateful battle he was wounded.

He was born in Dublin in 1888 and educated at the Royal Military Academy, Sandhurst, being gazetted into the Royal Dublin Fusiliers. He was in the process of joining Sir Ernest Shackleton's expedition to the North Pole when World War I broke out. He fought at Mons, was captured by the Germans, and several times re-captured in his endeavours to escape. Dobbs later served in the Allied Expeditionary Force to Russia in 1919. He was then seconded to the Egyptian Army, serving in the Sudan with the Police Force. After emigrating to South Africa in 1924 he farmed in Northam, Rustenburg. He died on 6 November 1956 , at the age of 68 .

He commenced his service in the 1st SA Irish Regiment as a Captain (T/Major) in B. Coy. Lt Col Dobbs's character was marked by three distinctive traits. The first was that of fearlessness and valour. The second was a harsh, autocratic exterior. Third, he possessed a profound devotion to the men of his Regiment. With regard to the first point, his courageous character, this made a deep impression upon Lt Col Cochran. The latter vividly recalls the first time that the Battalion came under enemy fire, at Banno, during the course of the Abyssinian Campaign':

'John Dobbs and I were standing together. We were the leading company and as we were moving through the bush the fire started. This was my first occasion of having a bullet whistle past one's ear and I immediately got down and knelt on the ground, to be a less obvious target. John Dobbs just remained standing there. I said to him, "For God's sake get down Sir". And he gazed at me with a sort of contemptuous look on his face - it was a look that I never forgot.

Mr R.M. ('Dick') West, who gained the Military Medal (MM) at Sidi Rezegh whilst serving with the SA Irish Regiment, and whose experiences recur throughout this article, remarked on $\mathrm{Lt}$ Col Dobbs's character ${ }^{2}$ :

'My impression of Col Dobbs was that he was the bravest man that I have ever met in my life. He was completely fearless and impervious to anything that might happen to him. At Mega [cf below] I saw him get up from cover and march towards a machine gun. At Sidi Rezegh B. Boy, in which I was serving, was called upon twice by Maj Cochran to launch an attack at the aerodrome. We had to get out of our slit trenches and march across a flat piece of ground, clearly outlined on the horizon and immediately visible to the Germans, who opened an intense fire upon us. On two occasions we found Col Dobbs standing there and watching the Germans. On each occasion he said, "What are you men doing here?" We replied, "We've been ordered to come here." He yelled at us to retire, and by so doing saved many of our lives on each 
occasion. He was eventually wounded on that spot. I saw him also before Sidi Rezegh, when we were attacked by two Messerschmitts, and one of the Bren gunners opened fire on the aircraft, which was eventually brought down by the collective fire of our battalion. Dobbs simply stood here, quite impervious, watching. Wherever the fighting was thickest, Dobbs was in the midst of it.'

Fr Nolan cited several instances of Dobb's deep attachment to the men of his Regiment ${ }^{3}$. One occasion occurred at Sidi Rezegh, when $\mathrm{Fr}$ Nolan remembers that Dobbs was carried in on a stretcher into a field ambulance. The former was told to make his OC secure in a shellhole and to ensure that Dobbs was as comfortable as possible. After Fr Nolan had placed Lt Col Dobbs in a slit trench the latter said

"'Patsy, are any of my boys here?" I said, "Yes, there are Sir." He said, "get round to them and say that I'm damn sorry for them."'

On another occasion, after Fr Nolan had returned to the Union, he met Lt Col Dobbs, who berated the Padre for not having visited the families of all the men of the Regiment who had been reported as casualties, or Prisoners-of-War. Dobbs stated that he had spent his entire leave visiting these families*. This point is confirmed by his obituary**:

'When he came back from the Middle East, he took it upon himself to see as many as possible of the families of men of his Regiment who had been killed on service.'

Dobbs emerges from the reminiscences of $L t$ Col Cochran and Messrs West and Schultz, as one who could never be considered a remote figure, but who was never liked due to the harsh image of the martinet that he projected. The impression which the pronounced authoritarian aspect of his character generated is conveyed by $\mathrm{Mr}$ West, in the following extract from his memoirs ${ }^{4}$ :

'... I recall part of a speech made by Major Ward Clare at [Gilgil] before we left for Mount Marsabit. He said, "The SA Irish have proved to Col Dobbs, in our recent manoeuvres, that we can be led and not driven." This was a very brave statement to make by any man in Col Dobbs's presence ...'

\footnotetext{
** Conversation between Maj (Fr) P. Nolan and S. Monick: 4 May 1989. **Indaba, December 1956.
}

Mr West, in conversation with the authors*, clearly remembers his Officer Commanding as pre-eminently a wartime soldier, careless concerning details of his personal dress. He certainly presents a vivid contrast with Lt Col Brennan (the OC of the SA Irish Regiment in South West Africa, during the period 1914-1915); in so far as the former could inject a sense of deep camaraderie within his Battalion; as is evidenced by the recollections of Fr Nolan and Messrs West and Schultz. Obviously, Lt Col Dobbs was greatly distanced, as a regimental commander, from Lt Col Brennan, in two major respects. First, the former had received the training of a professional army officer; and, secondly, Dobbs had experienced the traumatic conflict on the Western Front. Lt Col Dobbs was also most dissimilar from his predecessor, Lt Col Somerset, who emerges as a most approachable and well-liked officer.

Mr West vividly recalls** the parade at which it was announced that Lt Col Dobbs would henceforth command the Regiment. It occurred to the former that the new OC (whom he remembers as incongruously wearing boots with cavalry spurs) appeared to be extremely ill-tempered, as though reluctantly compelled to assume command through force of circumstances. The parade occurred immediately prior to the Battalion's departure for East Africa, when its personnel had returned from nine days embarkation leave. Maj Ward Clare then assumed the role of second-in-command.

\section{Fr Patrick ('Patsy') Nolan}

At this juncture, it is apposite to discuss the role of $\mathrm{Fr}$ Patrick Nolan in the Regiment's history. He was born in Dublin on 26 August 1902. Fr Nolan vividly recalls the 'troubles' of 1916-1922, and especially its commencement with the Easter Rising in Dublin, in April 1916. He became a member of the Order of Servite Monks and in 1917 went to England. The Order's Priory was situated some $5 \mathrm{~km}$ from Oxford. In 1922 he returned to Ireland and, at the end of 1923 , was sent to Italy, in which country he completed his higher education and was ordained. He returned to South Africa in 1935, to found the Transvaal branch of the Order, at Heidelberg. With the outbreak of war he sought a Chaplaincy in the Army, feeling that his fluency in the Italian Ian-

\footnotetext{
*Jointly, with Mr J. Schultz: 4 April 1989

** Ibid footnote * above.
} 


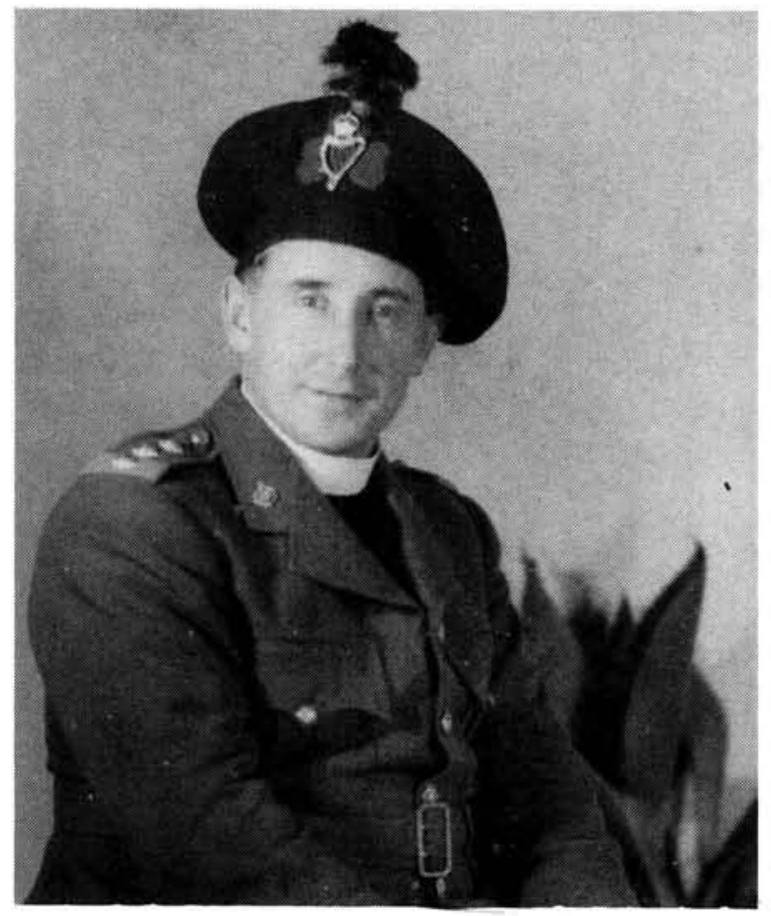

Father Patrick Nolan. Photograph taken November 1940

guage would be an asset in the light of Italy being one of the Axis powers. [This proved to be a completely accurate assessment, as his facility in Italian was a crucial factor in the assistance that he was able to proffer to fellow prisoners-of-war at the camp in Benghazi, following the battle of Sidi Rezegh. Fr Nolan recalls that, when he applied for a Chaplaincy, there was an unwritten rule within 5 SA Infantry Brigade that the Anglican Chaplain served at Brigade Headquarters, the Presbyterian and other Free Church Chaplains were sent to 3 Bn Transvaal Scottish, the Dutch Reformed Church Ministers were based with the 2nd Bn Botha Regiment; and the Roman Catholic padre, predictably, served with the South African Irish Regiment. To reiterate, Fr Nolan joined the Irish one-two months prior to its embarkation for East Africa. Following his repatriation in December 1941 he returned to Egypt as the Senior Roman Catholic Chaplain; followed by his appointment as Principal Roman Catholic Chaplain, based at Cape Town, in late 1944. Following upon his demobilization at the end of the war, he visited Ireland and then returned to South Africa. He was then transferred to Perth, Western Australia, where he spent 12-and-a-half-years.

Upon his return to the Union he was visited by Maj (later Cmdt) G. van Kerckhoven (OC of the 1st SA Irish Regiment during the period 1965-1969), pleading with Fr Nolan to return to the SA Irish as their Chaplain. Nothing could have given the latter greater pleasure; and since 1964 he has served as the Regiment's Honorary Chaplain.

The above details of Maj (Fr) Nolan's career, lacks colour and depth. It fails to convey the high degree of Fr Nolan's dedication to the Regiment, and the strength which the unit has derived from his spiritual guidance and support. However, this deficiency is surmounted by the citation which accompanies the award of the Order of the Star of South Africa (Non-Military), in the Class of Officer, with which Fr Nolan was invested on 20 October 1988. The citation emphasizes his devoted service to the 1st SA Irish Regiment, dating back half a century, and reads as follows:

'Father Patrick Nolan has dedicated his entire life to serving his fellow man and in particular tending to the needs of South Africa's men in uniform and their families. His spiritual and moral guidance has proved a most powerful uplifting force to many a down hearted soldier.

Father Patrick Nolan rendered distinguished service to Allied Prisoners of War after the battle of Sidi Rezegh in 1941 where he was himself a prisoner and suffered the same hardships. He has attended every Sidi Rezegh Memorial Service since the war and has conducted the service and provided a sermon regardless of personal discomforts occasioned by illness or bad weather. He has attended every annual visit to Barberton for the Rededication of the South African Irish Regimental Association Plaque erected at the war time camp site where the regiment was in training. He conducts the services and delivers a sermon. In addition he conducts the Sunset Parade Service held by the MOTHS of the Lone Tree Shellhole, also being a member of a local Shellhole.

He attends all funerals of Association members and when asked, conducts the service regardless of religious denomination. Each month he attends a meeting of Association members and at every meeting he is called upon to conclude the proceedings with a contribution, which is appreciated by members.

His spiritual guidance is extended to all families in time of distress and trouble, and he makes a point of trying to keep abreast of 
family affairs in order to enjoy their happiness as well.

In spite of a major operation at his age he manages to do all the above and in addition his keen sense of Irish humour is a legend and joy to all. His great popularity among his own church members is well known, as also to members of other denominations. This trait has made the Association and the Regiment well known and popular...'

Fr Nolan informed one of the writers, S. Monick* of his profound love for the Regiment. He stated that his life had been deeply enriched by the cameraderie which he had experienced whilst serving with the Regiment and which so fundamentally animated his comrades in the 1st South African Irish. He is most thankful, he stated, for having had access to such an experience, which he might otherwise not have confronted.

Mr Schultz recalled ${ }^{\star \star}$ that RSM Brehem, who was a great friend of Fr Nolan, had enormous respect for the padre, whom he considered to be a real fighting soldier, always in the midst of activity. When RSM Brehem attempted to prevent Fr Nolan from serving in the front line at Sidi Rezegh, the latter sharply reprimanded the former. This aspect of Fr Nolan's service with the Regiment is dramatically expressed in the following incident which occurred on 20 November 1941, as related in Fr Nolan's typescript notes. The episode occurred whilst Fr Nolan was serving with 11 Field Ambulance. Fr Nolan writes (pp 3-4):

'... it became imperative to evacuate the wounded as soon as possible. We worked until the afternoon when we got these casualties away and jumping into our trucks went forward to contact the Brigade which had moved still further ahead. It was while attempting to do so that we in the Field Ambulance had a rather hair raising adventure.

The first indication that I had of trouble was when I saw a truck ahead of me stop and the driver jump for cover. Cover is rather a grandiose word for what the desert presented in that way. There was nothing but a few isolated bits of scrub about a foot high. I called to my driver and together we ran as far from the truck as we could

\footnotetext{
*4 May 1989

${ }^{\star \star}$ Conversation (jointly with Mr R. West) with authors: 4 April 1990.
}

and laid down on the ground behind a bit of scrub, and on looking up to the sky found, I should imagine, between 40 and 50 German planes which were bombing and machine-gunning our formation. [This experience is recounted in Mr West's memoirs, as occurring on 20 November 1941]. They flew right across us dropping their deadly loads and with so much machine-gunning and bomb explosions one wondered how many of us would come away alive. When the last plane was at a safe distance I walked back to my truck finding on my way a machine gun bullet within a few feet of where I had been lying. After mopping my brow and lighting a cigarette I looked round the truck and found that no harm had been done. I was very grateful that the piece of shrapnel within an inch of my eye had not gone further. I did not relish the idea of having tyre trouble with the trouble I already had. I went back to investigate the place where I had been lying and found, within a few feet of it, an anti-personnel bomb that had not exploded. My retreat, I should think, was even quicker than the explosion would have been. Two or three hundred yards behind me I found a young fellow suffering from shell shock, and on enquiry found that he had woken up from the shock to find himself, covered with dust and sand, lying on the edge of a bomb crater.

We got back to our trucks and pushed forward, but by then the darkness had fallen and to my horror I found that a part of our Field Ambulance was following the wrong trucks. In this part of the Field Ambulance I was the only officer and the job of making contact with the rest of the Ambulance fell upon me. I stopped our ambulances and trucks and taking a bearing went forward with less confidence in the stars than in the hope in my heart. After some trouble I found those whom I was seeking and with a little luck returned to my own group and led them forward, I went to sleep that night with a great feeling of satisfaction in my heart that amongst my other jobs I had also successfully carried out some navigation...'

\section{Lt Col C. McN. Cochran, DSO, MC}

Lt Col Cyril McNalty Cochran entered the Regiment in June 1940. He had a most unusual background for an infantry officer, being a qualified dentist. Born in Johannesburg in May 1912, he was of Irish extraction. Cochran's grandfather had migrated from Ireland to Australia, and the Anglo-Boer War of 1899-1902 was the medium through which the family settled in South Africa. 


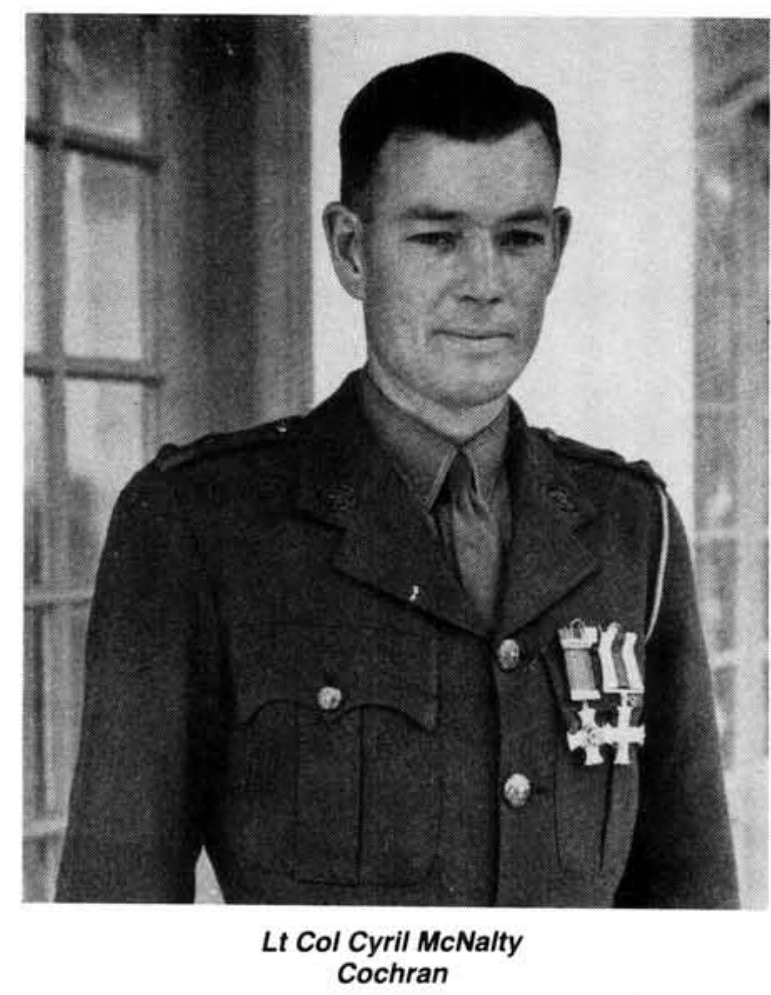

His father, John Cochran and his uncle, Frank Eardley Cochran, joined the Australian contingent that served in the Second South African War and, at the close of hostilities, settled permanently in South Africa.

With the outbreak of World War I, Frank Cochran, his uncle, joined 1 South African Infantry Brigade and rose to the rank of Brigade Major. At one point he commanded 2 SA Infantry Brigade (during the ill-starred 3rd Battle of Ypres, commonly referred to as Passchendaele (1917)) and the conspicuous gallantry that he displayed in that horrendous conflict was rewarded with the Distinguished Service Order (DSO). He was killed, in the midst of a further act of gallantry, during the battle of Marrieres Wood (March 1918), which occurred during the desperate retreat in the course of the 2nd Battle of the Somme. An officer, and some 300 men, had begun to withdraw under the impression that a general retreat had been ordered. Maj Cochran and two comrades exposed themselves to intense machine gun fire in an endeavour to halt the withdrawal. The retreating party at once returned to the firing line, but Cochran was struck in the neck by a machine gun bullet and died within three minutes.

A powerful motif exemplified by the Cochran family was sporting prowess, which powerfully shaped the character of both South African Irish regiments. Frank Cochran (ie Cyril's uncle) was a most accomplished tennis player, representing South Africa in matches at home and travelling to England to participate in the Wimbledon tournament.

Cyril Cochran was educated at King Edward VII School and qualified as a dentist at the University of the Witwatersrand, completing his training at Dublin. Whilst at the university he commenced his compulsory peace time training with the Transvaal Scottish, which had to be abondoned due to his studies. When he returned from Ireland in 1937 he joined 5 SA Field Ambulance as a Lieutenant. During the time that he spent at the University of the Witwatersrand, Cyril Cochran enhanced the sporting tradition of his family by gaining half-blues for boxing and hockey, and also playing hockey for the Transvaal.

The pronounced military traditions of his family proved to be of far greater weight than his professional training, and in 1940 he persuaded Brig Orenstein to agree to his transfer to a fighting regiment, which was to be the South African Irish. He joined the battalion as a 2 nd Lieutenant, and within a few months had risen to the rank of Lieutenant (holding the post of Adjutant). On the eve of the Regiment's embarkation for East Africa, he had been promoted to Captain and placed in command of C. Coy. Lt Col Cochran is a most prominent personality within the history of the 1st SA Irish Regiment; gaining the Military Cross (MC) for the gallantry that he displayed at Mega (cf below). He succeeded Lt Col Dobbs as OC after the latter had been wounded at Sidi Rezegh and orchestrated the break out of the survivors. He was awarded the Distinguished Service Order (DSO) for his services with 4 New Zealand Brigade, immediately following Sidi Rezegh. Upon the deactivation of the SA Irish Regiment, which Cochran had commanded during the three months following Sidi Rezegh, Cochran was appointed Officer Commanding the 2nd Regiment Botha in March 1942. His active service in World War II ended in the Western Desert, when, in late August 1942, he was severely wounded by shrapnel from the burst of an 88 $\mathrm{mm}$ shell, and invalided to the Union.

Mr Schultz distinctly remembers Lt Col Cochran as a cool, resourceful officer, in whom he had great confidence. ${ }^{*}$ He draws an interesting com-

\footnotetext{
${ }^{\star}$ Conversation (jointly with Mr R. West) with authors: 4 April 1990.
} 
parison between Lt Cols Dobbs and Cochran. The former he categorizes as an officer of the same character as Lt Col Kirby, OC of the 3rd Transvaal Scottish who was killed on 22 October 1941; viz of an impetuous, 'daredevil' disposition. In sharp contrast, Cochran was of a calculating and precise character.

It should be noted that the military career of his brother, Lt Col Frank Cochran, was closely interwoven with the history of the SA Irish Regiment. Indeed, in this respect the Cochran family has exerted a deep impression upon the Regiment. For Frank Cochran served as the Irish Regiment's first post-war Officer Commanding. During the war he had commanded 7 Field Battery, Transvaal Horse Artillery, in the Abyssinian Campaign, and 8 Field Battery in Libya (with the rank of Captain). During the Battle of Sidi Rezegh he had served as Battery Captain in 9 Field Battery, 3 SA Field Regiment (the THA in a re-structured form) the THA had furnished vital artillery support to the SA Irish Regiment during the Abyssinian Campaign (during the Battle of Banno) and at Sidi Rezegh. Lt Col F.H.G. Cochran, OBE, ED, served for a brief period as OC of the Transvaal Horse Artillery (September-October 1945). He was subsequently appointed Officer Commanding the resuscitated Irish Regiment, then designated 22 Field Regiment, South African Artillery, and fulfilled this role until 1951.

Thus, through the medium of the Cochran family, the history of the Transvaal Horse Artillery is interrelated with that of the 1st SA Irish Regiment. The two regiments' interaction is underpinned by the appointment of Lt Col Frank Cochran as the first post-war OC of 22 Field Regiment, which embodied the reincarnation of the 1st SA Irish Regiment. The Transvaal Horse Artillery, which had borne a strong relationship to the Irish regiment within the operational context, in Abyssinia and North Africa, thus proved a highly significant tributary during the post-World War II years. [To a large extent, such an interaction was shaped by the Irish Regiment's altered status as an artillery unit, which would naturally determine the selection of Officers Commanding from the senior echelons of the Artillery Corps. Within this context, it is noteworthy that one of the post-World War II Regimental Sergeant Majors of the resuscitated Irish corps, C.E. Whiller, MM, who served as Regimental Sergeant Major during the period 1946-1951 had emanated from the Transvaal Horse Artillery, which he had joined in 1936.

\section{Maj A.W. Clare}

Maj Alfred Ward Clare exercised a highly important dual impress upon the 1st South African Irish Regiment. First, he was instrumental in the formation of the corps. Second, he was prominent in the officer echelon, succeeding Lt Col Dobbs as second-in-command. His personality was such that he occupied an enduring place in the memories of Lt Col McGarity (Fr Nolan's predecessor as Padre), Mr West, Mr Schultz and undoubtedly many members of the Battalion, irrespective of rank. His death, on 19 February 1941 , as the result of a land mine explosion during the struggle for Mega, two days earlier (cf below) was undoubtedly a most tragic blow for the Regiment.

Maj Clare was a distinguished and highly respected figure in the Roman Catholic social and business circles of Johannesburg, as the following obituary in The Star, dated Saturday 22 February 1941 , clearly bears witness:

\section{'Death of Maj A.W. Clare}

Fatally wounded in action

... At the outbreak of war Major Clare was prominently connected with the formation of an Irish regiment, of which he was second in command at the time of his death. He joined the Army in the last war when he was barely of military age. He was wounded so severely that for a year the doctors despaired of his life. During a period of recuperation in the South of France he met Captain Seligson, and after the armistice they came to South Africa and founded the firm of Seligson and Clare Ltd. Captain Seligson died three years ago and Major Clare became managing director of the company.

\section{Ardent church worker}

Major Clare was exceedingly respected by the Roman Catholic community of Johannesburg. For many years he devoted much of his time to the work of the St Vincent de Paul Society. His untiring labours and wise counsel were greatly respected by the Central Council of the Society, but his special interest was the activities of the Rosebank conference, of which he was the first president. Indeed, nowhere will his death be more sincerely mourned than among the families of the Craighall district in whose interests he laboured so tirelessly. 
He was closely identified with the parish life of the choirmaster.

He was keenly interested in music and was an active member of the Ambrosian Male Voice Choir and also of the Johannesburg Catholic Choral society.

Paying tribute to Major Clare, one of his friends said: "The most wonderful thing he ever did was to go into the army again. $\mathrm{He}$ was severely wounded in the last war, and did not join up this time with any false idea of the pleasures of war. He knew what he would face and he faced it. His friends will remember him as 'The Happy Warrior' who did his duty."

Major Clare leaves a widow and five children, four daughters and one son.'

The above quoted obituary strongly implies the highest degree of commitment and dedication on Maj Clare's part, in electing to serve the SA Irish Regiment in a combatant role, as a senior officer; in view of the fact that his wounds, sustained in World War I, had almost cost him his life.

\section{THE STRATEGIC SITUATION IN EAST AFRICA, NOVEMBER 1940 (cf Map 1)}

Italy had declared war on the Western Allies on to June 1940, coincidental with the conquest of Western Europe by the German armies, which was completed that month by the surrender of France. The evacuation of the British Expeditionary Force from Dunkirk had left Britain in an extremely exposed position in relation to Italy's threat to the crucial Suez Canal. France's capitulation obviously resulted in the withdrawal of the French colonial army from the East African theatre, whilst the South African, New Zealand and East and West African forces had yet to be mobilized. Although the majority of Britain's army had escaped by sea, the great proportion of its heavy weapons and equipment had been abandoned; and, in this pathetically unarmed state, Britain confronted the imminent threat of invasion. Italian forces were posed to sever the British supply routes through the Mediterranean to the Middle East, up the Red Sea and traversing Africa from Takoradi to Khartoum.

On the southern fronts the Italian forces in Eritrea and Abyssinia amounted to more than 200000 men. Five weeks after Mussolini's declaration of war, the Italian strength in East Africa was estimated to be 255000 , of whom 95000 were Whites. This proved to be a remarkably accurate assessment, as the precise figure, on 1 June 1940 , was 255950 , which could be supplemented by a further 35226 drawn from the Carabinieri, Customs Guards, Police, Navy and Air Force. By the beginning of August, the strength of the Italian forces, supplemented by irregulars, had increased to 112731 Europeans and 258322 indigenous recruits; a total of 371053 , including the Navy and Air Force. The most effective troops were the regulars of the Savoy Grenadier Division. This comprised: a regiment (consisting of two grenadier - or infantry - batallions and one Bersaglieri battalion); an Alpine regiment of three battalions; a Blackshirt Legion totalling three battalions; an artillery regiment; some cavalry; a machine gun battalion and a light tank squadron. None of these units were positioned on the Kenya frontier.

The second main component of the Italian forces based in East Africa was the Cacciatori d'Africa Division. This was composed of locally recruited Italians; it included Blackshirt battalions whose main function was the control of rebellious elements among the tribesmen, especially in the province of Shoa and in Addis Ababa itself. Thus, the Duke of Aosta's only professional soldiers were included in the Savoy Grenadier Division; the only exceptions being in the artillery, engineer and other specialist units. The bulk of the white soldiery in the Africa Division were poorly trained and poorly equipped, and commanded by officers with no experience of modern warfare. These Fascist militia were devoid of motivation. Being settlers in the region, they were understandably most apprehensive and reluctant to leave their families at the risk of rebellious tribesmen.

The third major element in the Italian East African forces consisted of Colonial native troops. Their fighting prowess - and loyalty - fluctuated widely. The veteran Eritrean Brigades possessed a history dating back to 1889 and were regular troops. They were the equal of any professional black soldiers in Africa, and engendered the respect of friend and foe alike. The Somalis were also included in this element and some (including the native colonial police, or Zaptie) were resilient and cunning fighters. The more recently recruited Abyssinian and other native levies were of a far more dubious and 
unreliable character. Not only were they half trained, but were virtually impossible to organize and control, as very few Italian officers, or even native non-commissioned officers, could communicate with them in their language. [The same problems arose with African regiments on the Allied side (eg. the King's African Rifles, Nigerian and Gold Coast battalions), in which the European officers and non-commissioned officers were often unfamiliar with the language of the men in the ranks.] In addition, there was a category of Italian irregular native troops - indiscriminately termed 'Banda' - who patrolled the extensive no-man's land along the borders of the Italian East African empire.

When Italy declared war on the Allies, Mussolini's forces in Italian East Africa were organized as follows:

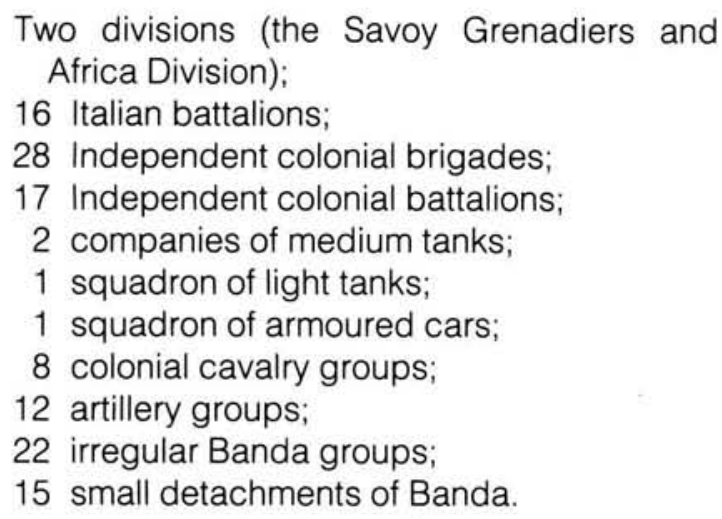

The Duke of Aosta could deploy 39 light tanks and 126 armoured cars or vehicles protected by armour plating; in addition to more than 800 guns, ranging from four $149 \mathrm{~mm}$ howitzers to 24 Breda $20 \mathrm{~mm}$ anti-aircraft guns. In addition his forces possessed 71 excellent $81 \mathrm{~mm}$ mortars, which considerably outranged the 3 inch mortar utilized by the South African Division, together with a further 57 mortars of $45 \mathrm{~mm}$. However, the numerical impressiveness of this range of artillery concealed their obsolescent character, as many of the pieces dated back to World War I, and some even to the end of the 19th Century. [However, this antique artillery was not greatly disadvantaged by that of the opposing East African force, which never possessed a field gun more modern than that of the $18 \mathrm{pr}$ (introduced 33 years earlier and completely obsolescent within the British Army) and was dependent upon obsolete Lewis guns for anti-aircraft protection in the field].

These forces were distributed over four military commands, contained within the following sectors: (i) The Northern Sector (Lt Gen Luigi Frusci); continguous with the northern Sudan. Maj Gens Vincenzo Tessitore and Agostini Martini commanded the troops in Eritrea and Amhara respectively.

(ii) The Southern Sector (Lt Gen Pietro Gazzera); fronting the southern Sudan and northern Kenya. This command encompassed the entire Galla-Sidamo province and a small section of Somalia, as far as Dolo. The 2nd and 5th South African Brigades were to be heavily involved in this region.

(iii) The Eastern Sector (Lt Gen Guglielmo Nasi, with Lt Gen Sisto Bertoldi as his deputy). This enormous command bordered French and British Somaliland. It encompassed the provinces of Harra (Maj Gen Carlo de Simone); Shoa (Lt Gen Ettore Scala) and Dancalia (north of French Somaliland); Dessie; Addis Ababa; the Ogaden between Harrar and Belet Uen; and the coastal regions of Somalia northwards from Harardera. Brig (later Maj Gen) Pienaar's 1st Brigade largely operated in this theatre.

(iv) The Juba Sector (Lt Gen Gustavo Pesenti) comprised that region of Somalia bordering on Kenya, extending from the sea up to Maudera. This sector thus embraced the entire Juba river line, threatened Mombasa and dominated the strategic apprehensions of the Alied East African force.*

These forces could advance westwards into the Sudan, defended by a paltry 9000 British and Sudanese troops, or southwards into Kenya, which was defended by an equally meagre garrison. On the North African front, an even larger force in Cyrenaica, commanded by Marshal Graziani, menaced the 36000 British, New Zealand and Indian troops defending Egypt. The foremost British position was based at Mersa Matruh, $212 \mathrm{~km}$ inside the frontier and some 500 $\mathrm{km}$ west of the Nile Delta. The British position was profoundly aggravated by the fact that the Italian naval presence rendered the sea route through the Mediterranean too vulnerable, and reinforcements had to be despatched via the far longer Cape route, down the west coast of the African continent and up the east coast into the Red Sea. The logistical problems which had to

\footnotetext{
*The principal secondary source whence the information detailing the strengh and disposition of the Italian forces in East Africa has been derived is as follows: Orpen, Neil, East African and Abyssinian campaigns. Cape Town, Johannesburg: Purnell, 1968, p. 18, 19-20. (South African Foces in World War II, Vol. 1.)
} 
be thus encountered is clearly illustrated by the fact that a small reinforcement of 7000 troops, ready for despatch in May 1940, did not arrive in Egypt until the end of August of that year.

The Fascist forces were thus in an excellent position to have effected a major Italian victory both strategic and historical - by executing a massive pincer movement to the east and south by Graziani's armies, and west and north by the Duke of Aosta's Abyssinian forces. No resources were available to reinforce the fragmentary British armies that guarded Egypt and the Sudan against the imminent threat of invasion presented by the Italian armies - overwhelmingly superior in numbers - from their bases in Libya and East Africa. Such a pincer movement would have embraced Egypt and Suez within its grasp and thus sealed the Suez canal; closing the Red Sea supply route to the British Army of the Nile. At the end of August 1940, therefore, the enemy enjoyed an extremely powerful position in the crucial theatres of North and East Africa. Italy controlled the southern entrace to the Red Sea. No obstacles to an Axis sweep through the Sudan confronted Mussolini's forces; whilst, in Libya, Graziani's armies were based at Sidi Barrani, in a position to launch an attack in overwhelming force on the Nile.

Fortuitously, from the Allies' viewpoint, the Italian exploitation of their enormous strategic assets was marked by considerable hesitancy and inefficiency. Mussolini's armies commenced, on 4 July 1940, with two small frontier encroachments, at Kassala and Gallabat in the Sudan; on 10 July at Moyale, on the Kenya frontier. The Italian forces moved from Eritrea and occupied Kassala, some $18 \mathrm{~km}$ from the Sudanese frontier. The Axis attackers consisted of two brigades (approximately 6500 men) to seize an outpost defended by a double company (some 300 men) of the Sudan Defence Force. The military commander in the Sudan, Maj Gen William Platt, could call upon only three infantry battalions for the defence of the enormous area under his command, based respectively at Atbara, Khartoum and Port Sudan. He sagely decided not to commit his meagre forces until he was aware of the precise character of the Italian invasion. After occupying the frontier posts at Gallabat, immediately beyond the north west frontier of Abyssinia, and Moyale, situated on the northern frontier of Kenya, Mussolini's forces halted. Only in August did the Italian forces commence a more serious offensive drive. The objective was British Somaliland, the strip of coastal territory on the African shore of Aden. Even this limited manoeuvre was conceived in defensive terms. The Italians had been ordered to maintain a defensive posture. However, the Duke of Aosta, the Viceroy of Abyssinia and supreme military commander in that sector, had determined upon the occupation of British Somaliland. He felt that the port of Djibouti, in French Somaliland, afforded ready egress into Abyssinia, via British Somaliland, and did not trust the Armistice agreements with the French. Thus, he decided to occupy the larger and adjoining area of British Somaliland, to seal off this avenue of possible invasion into Italian territory.

British Somaliland was defended by the British garrison, consisting of four Abyssinian and Indian battalions; a British battalion (the Black Watch) being en route as reinforcements. The garrison commander was Brig A.R. Chater. The Italian invading force consisted of 26 battalions, supported by artillery and tanks. But its advance was delayed by the small Somaliland Camel Corps. The main British force, under Maj Gen A.R. Goodwin Austen, arrived on the scene just as the invaders reached the Tug Argau Pass, on the approaches to the seaport capital of Berbera. At this point the defenders maintained such a resolute defence that the Italian forces were kept at bay in a four-day battle. However, the Imperial troops were eventually compelled to evacuate their positions by sea from Berbera, in default of further reinforcements and defensive positions, in an exercise which contained overtones of Dunkirk. The force which had thus been withdrawn from Berbera was, in the main, despatched to Kenya, to augment the British forces being built up there. The troops which had defended British Somaliland so tenaciously had inflicted upon their attackers casualties in excess of 2000 , at a cost of barely 250 to itself. The deep impression which it had thus made upon the Duke of Aosta's forces may well explain, in large measure, the marked lack of initiative and resolution that was to characterize the subsequent response to the Allied invasion of the Italian East African empire.

It may be feasibly argued that, in veiw of the ease and rapidity with which Abyssinia was overrun by the Imperial, South African and other Commonwealth forces (in vivid contrast to the ardous campaigns fought in the other half of this double-theatre of war, North Africa), the threat posed by Mussolini's armies to the critical Suez supply link was over-estimated. However, hindsight is one of the most exact sciences, and one 
must appreciate the strategic situation in East Africa in November 1940, as it appeared to contemporaries.

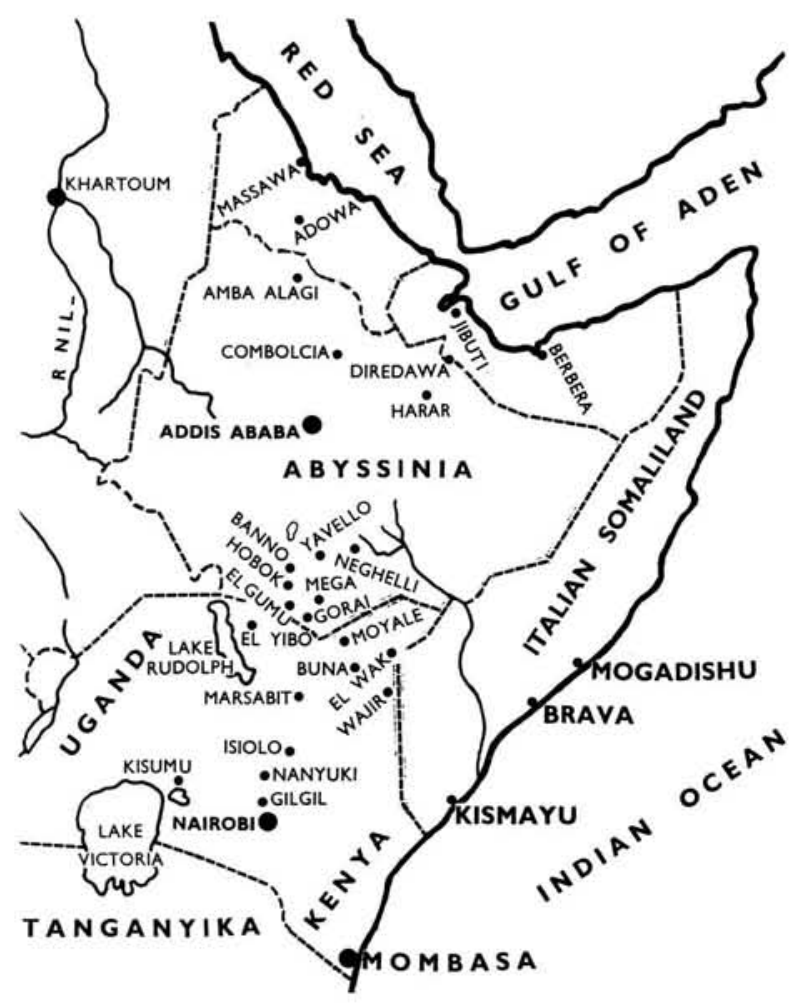

\section{Outline of Abyssinian campaign (cf Map 1)}

The Italian empire in East Africa was destroyed by a gigantic pincer movement. The northern arm of this pincer movement was composed of forces based in the Sudan, commanded by Gen Platt. Gen Cunningham's East African Force embodied the southern arm. The northern arm overran Eritrea and broke the heart of Italian resistance in this sector at Keren. The southern arm conquered Italian Somaliland, recaptured British Somaliland, broke through to Addis Ababa and finally destroyed the last vestiges of Italian resistance at Amba Alagi. The southern movement was of a two-fold character. From the vantage point of the South African forces, the 1st Brigade of Maj Gen (later Lt Gen) Brink's 1st SA Division approached Abyssinia from the south-west, via Italian Somaliland. It achieved a series of resounding victories, commencing at El Wak (16 December 1940). Breaking through the Juba River line, Pienaar's force advanced on Harrar, which yielded without opposition, and entered Addis Ababa, the capital, on 6 April 1941, the city also falling without offering any resistance; and ended the Abyssinian campaign with the hard fought battles of Comobolocia Pass (18 April 1941) and Amba Alagi (18 May 1941). The 2nd and 5th Brigades were directed towards the reduction of the strategic Italian bases of Mega, Yavello, Neghelli and Moyale, in the sector known as the Moyale escarpment. As part of this strategy, units of the 2nd Brigade advanced from Dukana to the strategic wells of El Yibo and El Sadia in the Lake Bulal region. This article will be principally concerned with the movements of 5 SA Infantry Brigade, in order to furnish a frame of reference for the service of the 1st South African Irish Regiment.

Abyssinia thus formed the very first theatre of war in which the UDF was involved. Essentially, the role conceived for the South African armed forces in August 1940 formed an extension of the military profile which the Union Defence Forces had assumed in 1914; viz confined to the African continent, and involved in bush and desert warfare.

\section{Prelude to the capture of Mega (10-14 February 1941)}

On 10 February a patrol of the SA Irish Regiment, together with a section of armoured cars, escorted several envoys of the Shifta to Hadu, the mountain citadel of the Shifta leader operating in the Gundile area, named Haile Degage. Several strong patrols from the Battalion also explored a large sector of the Gundile region.

On 13 February the 1st South African Irish Regiment commenced the operation which was to culminate in the capture of Mega, the climax of the Battalion's participation in the Abyssinian campaign. The powerful fortress of Mega dominated the southern defences of Abyssinia. It was positioned on a high mountain plateau, its surrounding hills ringed with heavy artillery, and manned by reputedly resolute battalions of colonial infantry. As it formed the centre of the southern defences, its loss rendered Moyale an untenable position for the Italians; as the capture of the Beau Geste style fort of Mega completed the outflanking manoeuvre of the South African forces with regard to the Italian positions in the Galla-Sidamo province. [Moyale had been captured by the Italians, who had overcome its small garrison (consisting of personnel from the King's African Rifles) soon after Italy's entry into the War. During the course of the South African forces' siege of Mega, the Italian garrison at Moyale effected its escape by a wide eastward detour to Neghelli.] Gen Brink envisaged 5 SA Infantry Brigade attacking from the north, whilst 
2 SA Infantry Brigade launched an assault from the east, simultaneously covering the MegaMoyale road.

Mega garrison consisted of two battalions (one European and the other colonial infantry). At 11:30 it was reported than an Italian attack had been launched, on the previous night, on a detachment of the Field Force Brigade, which had occurred on the Yavello road; evidently by the Italian column ordered to attack the Irish Regiment. A patrol of armoured cars was sent out to reconnoitre the road leading over a crest 2-4 $\mathrm{km}$ in front of the Battalion. The patrol turned back amidst bursting shells, after having killed or wounded two hostile motor-cyclists. In the afternoon of 14 February part of the perimeter was taken over by 3 Bn Transvaal Scottish.

\section{THE ASSAULT ON MEGA (15-18 February 1941)}

A striking illustration of fine war reportage is contained in the account of the capture of Mega, which appeared in The Star, dated Friday 28 February 1941:

'STIRRING STORY OF FALL OF MEGA TO RAND MEN/BRILLIANT OPERATION IN HEAVY RAIN AND BITTER COLD/BLACKSHIRTS SURRENDER

Three days of fighting in drenching rain and bitter cold preceded the capture of the strongly fortified Italian post of Mega, in the mountains of South-Western Abyssinia, says a communication issued by the Union Bureau of Information. Mega is encircled by hills, on which were Italian blockhouses, observation posts and machine gun nests, the whole protected by barbed wire entanglements and land mines. Again the Italians did not face the final assault, but surrendered when it was clear that the South Africans meant to storm the fort.

A unit from the East Rand attacked the hills in front and to the right of the fort, and two other units - mostly Afrikaans-speaking - made an encircling movement to the rear.

Fighting their way up the slippery hills, which rise to nearly 6000 feet above sea level, the South Africans completely surrounded the fort in spite of heavy artiliery and machine gun fire, and late in the afternoon of February 18 closed in on it with the mist, and the Italians surrendered.

The news reached South Africa two days later. The full story is given today by a representative of the Bureau of Information.

\section{BIGGEST VICTORY}

He says that a white flag fluttering behind the bastion of the red-walled fort signified not only the South Africans' biggest victory in Abyssinia so far, but the end of three never-to-be forgotten days and nights, in which the sheer physical endurance and dogged determination of the South Africans triumphed over almost incredible hardship. Soaked to the skin in almost continuous rain, in a temperature only a few degrees above freezing point, the men advanced ankle deep in mud across mountainous bush country, dragging their heavy support weapons for miles along steep goat tracks. An officer who gained the Croix de Guerre, with bar, in the last war described it as an achievement probably without parallel in modern warfare.

All the time the hills were being raked by enemy artillery, and minefields and concealed machine gun nests menaced every step.

On the night of the 18th, exhausted though they were, the men were exulting in the sight of their regimental standards flying from the fort, at the spectacle of a thousand prisoners (of whom fully 600 were European troops) and an enormous quantity of captured war material.

... [On the] night [of 15 February] the column camped alongside a volcanic crater - the most striking scene so far encountered. Dark clouds had been banking up during the day, and that night a heavy downpour sent the troops scurrying for shelter. With the dawn next day - Sunday February 16 - the sky was still heavily overcast, and a thick mist obscured the range of hills which were the first objectives of our troops.

\section{FIRST SHOTS OF BATTLE}

At ten o'clock four bursting shells announced that the Italians were waiting... 
The battle for Mega was on.

Aeroplanes were already overhead, and to the crash of enemy artillery was soon added the dull thud of bursting bombs and the violent clatter of anti-aircraft pom-poms and machine guns. The infantry had by this time left their transports, and were advancing on foot across the hills. Simultaneously other South African troops were making an encircling movement.

At midday the threatened storm broke. The rain poured down in sheets and soon the country was a dreary quagmire and the hills, into which hundreds of our troops had marched, were completely hidden in a thick mist. Fire, from both our troops and the enemy, was reduced to a few desultory rounds, and air activity was ended.

The main body of the troops camped at the base of the hills, and a few of the lucky ones whose position was invisible to the enemy were able to make fires, but the remainder spent the afternoon and night in bitter cold. Even the consolation of smoking was denied to one unit which was in a particularly exposed position.

The supply vehicles could not get through the mud, and that night there was only a tin of bully [beef] and a single biscuit for every four men. Yet they remained cheerful and sung until exhausted by their efforts that day they fell asleep.

\section{FEET MOUNTAIN}

Dawn brought no promise of relief from the weather, and in the hills the troops advanced slowly. The mud was ankle deep, and the bush so dense that the men had to turn their backs on it and push through.

At eight o'clock the South African Artillery moved up and the tempo of battle increased ... From every part of the range of hills came rifle and machine-gun fire, and every now and then explosions and more muffled fire told of opposition being encountered by the section of South Africans who, in their encircling movement, were scaling a $3000 \mathrm{ft}$ high mountain to the south of Mega. The enemy artillery was spasmodically active.

And then South African artillery went into ac- tion, and volley after volley crashed across the hills.

The progress of the infantry was slow, for its speed was entirely dependent on the rapidity with which the support weapons could be moved, and their achievement provides one of the most stirring chapters in this story.

\section{FIRST SUCCESS}

At midday a company of a well known Johannesburg unit scaled a high hill and put out of action an enemy observation post, which had with great efficiency been directing artillery fire from Mega. A serious menace was thus removed, but on the other side of the fort enemy artillery was still active, their shells harrassing our troops grimly scaling the heights.

All afternoon the slow advance went on under enemy fire, our replying fire being an almost continuous accompaniment. Just before 6 o'clock men of an East Rand regiment captured a machine-gun nest on a hill commanding the whole area through which the South Africans were advancing.

By now the infantrymen were dead beat, some of them scarcely able to move. It was decided to camp, and again the troops spent a miserable night. It was still pouring with rain and bitterly cold. During the night rations and blankets arrived by convoy after a journey that is a stirring story in itself.

\section{DEADLY ARTILLERY WORK}

Again at dawn the advance continued in pouring rain. The battle was entering its final phase.

Early in the day a Beau Geste fort came into view, and our artillery got to work with deadly effect. The guns had been manhandled into position at two o'clock on that bitterly cold morning, but the work was worth while, for enemy guns were soon silenced. Aeroplanes that had been bombing and machine-gunning the whole morning scored direct hits on one enemy blockhouse, killing everybody within it.

By this time a Johannesburg regiment had brought up its mortars, and the men of another blockhouse soon ran out, waving a 
white flag. There were 12 Blackshirts in this first batch of prisoners.

A little after 3.30 p.m. came the report that one unit was ready to test the main defences of Mega, soon followed by reports that other units, including those who had fought their way up the 3000 feet hill, would soon be ready to attack. Zero hour was fixed for 4.25 p.m., and the next hour was the most tense period of the whole battle. Thick back clouds swathed the hills, and the rain beat down mercilessly. Rumbling peals of thunder now and again drowned the sound of desultory mortar and rifle fire.

At one minute past zero hour the report came that the final assault had begun. The Johannesburg unit, with bayonets fixed, raced across a clearing and down the hillside towards the fort. The East Rand unit advanced from the other side, rifles and mortars in action.

\section{WHITE FLAG FLOWN}

Twenty minutes later an officer of the East Rand unit reported that through a break in the heavy clouds he thought he could see a white flag. The commanding officer peered through his glasses, but the mist had come down and he could see nothing. The advance continued.

Then the mist lifted for a fraction of a second, and there, flying from the high mast just behind the fort, was the white flag. The "cease fire" was given. Everything was quiet in the fort, but nothing was taken for granted, and the commanding officer ordered armoured cars and engineers to advance. Then from all the surrounding hills, from the village and the fort, streamed men waving white flags. There were so many of them that the commanding officer feared he would not be able to handle them all.

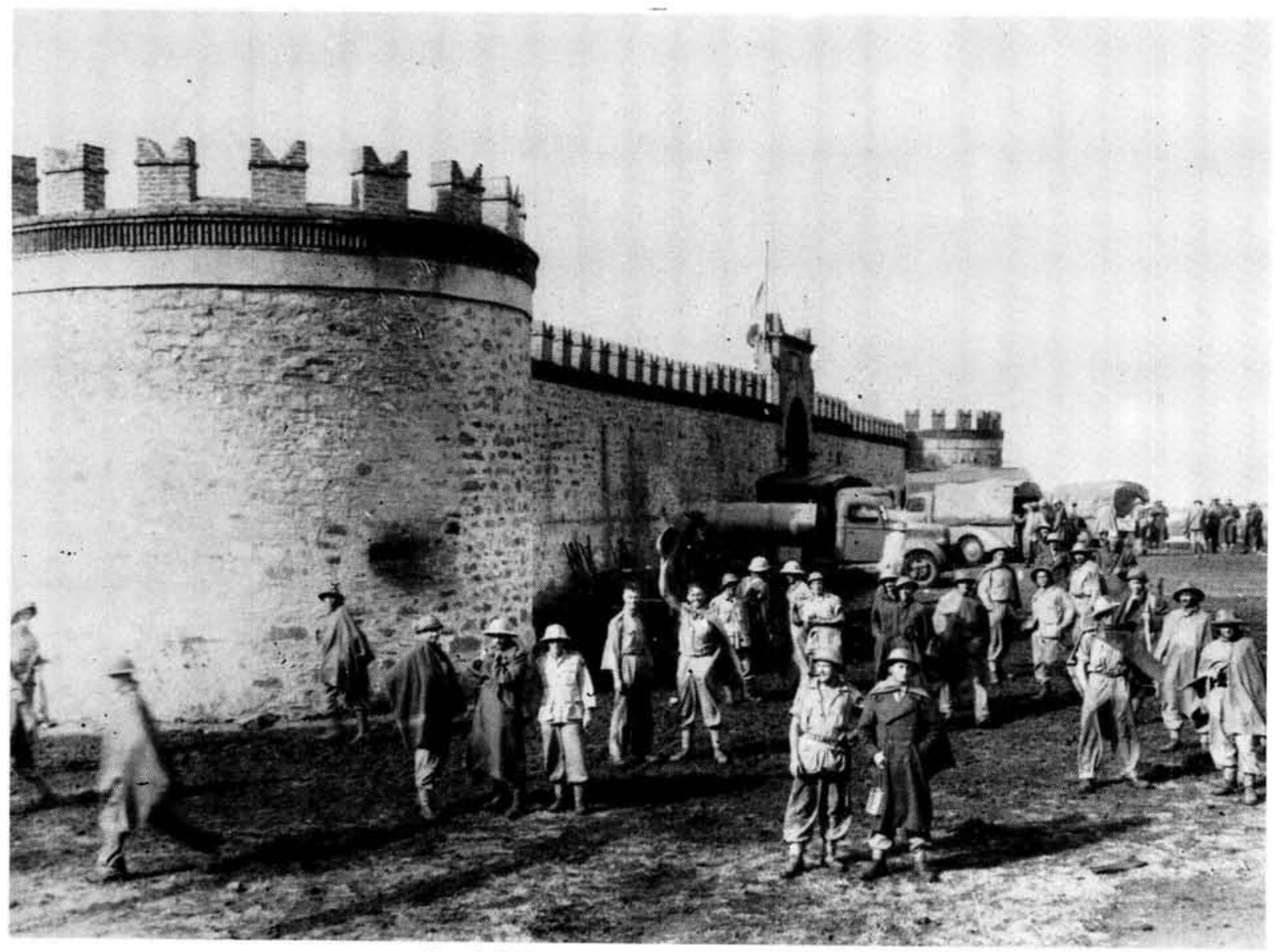

South African troops outside Mega Fort 


\section{FORMAL CAPITULATION}

Later an Italian captain came up and guided the commanding officer to the Italian colonel, who was also Governor of Mega Province. In front of the official residency, a white washed circular building, there was a dramatic scene. The Italian officer handed over his arms to the South African colonel, saying in French that he realized the futility of carrying on the fight and that to save life he had surrendered. In reply the South African colonel said that the Italian fort had put up a gallant fight and that the surrender was no stain on Italian honour.

The hundreds of prisoners were placed under guard and the South Africans took over Mega fort. But they took over no physical comfort. It was still pouring with rain, and another hard night was in store for them - but with this big difference, they could have fires to their heart's content, with thoughts of a splendid victory to give them inner warmth.'

The above report may serve as an outline, or external frame of reference, for the detailed study of the SA Irish Regiment's participation in the attack (cf below). Several significant factors are cited in the war correspondent's narrative, which have a direct bearing upon this episode in the Regiment's history. The first is the reiterated references to the appalling weather, which rendered conditions so miserable for the assaulting infantry. When the troops moved into the attack on the morning of Sunday 16 February, they were dressed in tropical shorts and shirts. They carried neither blankets nor greatcoats, which was not surprising in view of the fact that the temperature was in excess of 100 degrees Farenheit. The previous few months had acclimatized the South Africans to temperatures of 110 degrees Farenheit and above. They were thus totally unprepared for the rigours of the forthcoming night. Second, the land mines to which the report refers exacted their toll upon the Irish Regiment (including the death of Maj Ward Clare). Third, the 'well known Johannesburg regiment' which neutralized an enemy observation post was, of course, the 1st South African Irish Regiment, a company of which fought its way through minefields, rain and mist to successfully accomplish this hazardous and important mission. This was the same battalion which advanced through the rain and mist, bayonets fixed, for the final assault upon the fortress. These themes will be interwoven into the ensuing study, which will seek to expand those events recorded in the newspaper report that are germane to this story; principally through the medium of three primary sources (the Regiment's War Diary, the account of Lt Col Dobbs and $\mathrm{Mr}$ West's memoirs), supplemented by the Official History ${ }^{5}$ and a further valuable secondary source, detailed below.

\section{Advance on Mega delayed (cf Map 2)}

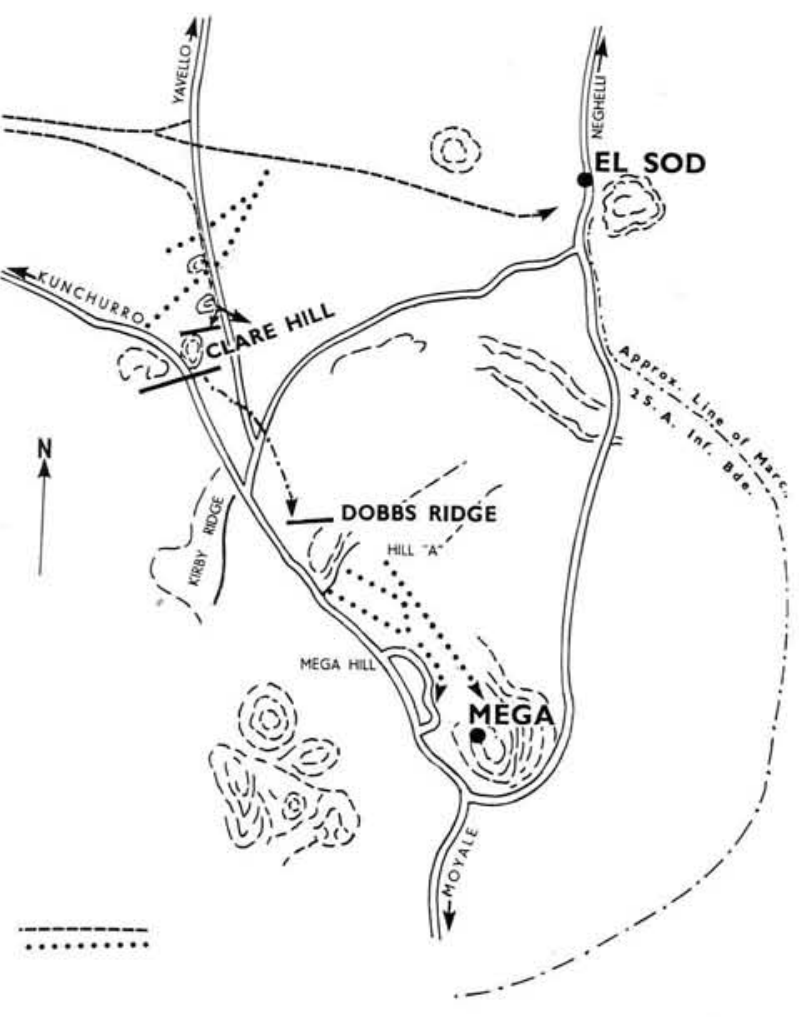

At 08:00 the 5th Brigade advanced; C. Coy of the Irish Regiment on the left of the YavelloMega road and $3 \mathrm{Bn}$ Transvaal Scottish on its right. (The remainder of the SA Irish Regiment was held in reserve, in order to protect the Brigade's rear; B. Coy being positioned on Clare Hill, where the Brigade $\mathrm{HQ}$ had been established and A. Coy and Support Coy in the Medaccio area). C. Coy included one section of Vickers machine guns, two sections of mortars and one section of anti-tank rifles, under the overall command of Maj Ward Clare. The objective of C. Coy was to occupy the high ground to the left of the Mega road, designated Dobbs Ridge; moving in collaboration with the 3 Transvaal Scottish, who were ordered to occupy the kopjes of Black Ridge and Kirby Ridge (the latter named after the battalion commander, who was to be killed on 22 November). The force would then pause 
and consolidate, permitting 2 SA Infantry Brigade to reach its assaulting positions. Two armoured cars screened the advance. Ominously, the greatcoats, blankets and groundsheets were left in the trucks (only ammunition, rifles and webbing being carried) when the Irish force debussed close to the Yavello-Ganciaro road. The Irish battalion made rapid progress over difficult ground. The first ridge ('Artillery Hill') and the Yavello road were traversed, following which the force moved up the right slope of Dobbs Ridge, from which point it commanded a view up the Mega valley. No enemy opposition was encountered, save shells which passed well overhead, directed at the cross roads. The Irish Regiment then remained stationary for four hours (between 12:00 and 16:00), awaiting the Brigade Commander's permission to advance. Rain had commenced falling at 14:00. Orders were received to the effect that the SA Irish Regiment and 3 Transvaal Scottish were to consolidate for the night, in order that their movements might be coordinated with that of 2 Brigade.

The source of this impediment to 5 Brigade was the unco-ordinated path of 2 Brigade, which was subject to both considerable delay and changed orientation. Brig Armstrong, who had instructed his force to proceed with extreme caution, was aware of the fact that 2 Brigade had not yet even left its bivouac at El Sod by 09:00. Shortly before the downpour of rain commenced, Brig Buchanan, the 2nd Brigade's commander, had informed Armstrong that the delay was the result of a suspected enemy convoy approaching from the north-east, and added that he hoped that the brigade would be in position one hour hence (ie. 14:45). The import of his communication suggested that he now regarded the severance of the Mega-Moyale road as his principal objective. At 15:35 the 2nd Brigade had accomplished this task, some $6 \mathrm{~km}$ south of Mega, through the agency of an advance guard of 1 Field Force Battalion, commanded by Capt Dane. Brig Buchanan apparently reasoned that this had implemented his brigade's first objective of preventing the enemy's escape southward. However, this objective appeared to be at variance with the divisional commander's conception of 2 Brigade's main task; viz the attack on Mega from the east. By the late afternoon Brig Buchanan had established his Headquarters some 7000 yards distant from the southern fortifications of the fortress. However, night had intervened before all his transport had been concentrated. In actual fact; the rear guard had to bivouac en route, as no lights could be shown. The progres- sively delayed commitment to Brig Armstrong that 2 Brigade would be deployed for the attack on Mega at 11:30, then at 14:45 (or at 15:00, as promised to Maj Gen Brink) simply had not materialized. Armstrong, at 18:00, despatched a message to 2 Brigade, requesting an assurance from Buchanan that the latter's force would be in a position to attack in sufficient strength to launch the attack at 07:00 the following morning, in order that the two brigades could initiate their assault at the same time. Brig Buchanan replied that he could thus monitor his advance, but qualified his assurance by stating that he saw little prospect of pressing his attack in any strength; due to Mega only being accessible via a narrow defile, and being flanked on all sides by impregnable cliffs.

Due to the greatly delayed advance of 2 Brigade, therefore, a night intervened prior to the assault on Mega, in which the expanded company of the SA Irish Regiment (in common with 3 Bn Transvaal Scottish) were subject to the most appalling conditions, as graphically recounted by Lt Col Dobbs 6 :

'There were no coats, no groundsheets, no blankets, no hot food or drink as the faint yellow twilight waned and the night closed clammily around us. Rations were down to a quarter of the usual scale - a few mouthfuls of bully beef with the rain pouring greasily over the dull white lumps of fat.

With their flimsy tropical clothing the men lay down in stony, shallow trenches that looked, and felt, like graves. They made the most of the dank, damnable darkness. There was no smoking; lights were banned, and streaming trees and bushes masked those who sought there shelter. Vague wreaths of mist swirled out of the deepest gloom like uneasy ghosts. The whole of the black heavens seemed to be weeping over the huddled figures in their trenches. And it rained and rained and rained. Somebody said that this was our reward for starting an attack on a Sunday.'

A combination of mud and enemy shelling rendered it impossible for the trucks to reach the forward troops with supplies. One of the members of $C$ Company stated that ${ }^{7}$ :

'Some bully [beef] did get through, but not enough to go round, so we all gathered round and the Company Sergeant-Major ladelled it out with a tablespoon - one spoon to each 
man's hands. We also managed to get some cigarettes and matches, and then put the cigarettes in our pockets. But in the morning it was raining again and, when we wanted a cigarette, it was all drenched and none of us could smoke unless you happened to have a celluloid tobacco pouch'

The troops had to dig themselves in with nothing but short entrenching tools.

The order to advance came in the bleak early hours of Monday 17 February. The assault on Mega being most seriously retarded, Maj Gen Brink sent a personal message to both brigade commanders, early on the morning of 17 February, stressing the importance of pressing home the attack that day, in order to deprive the Italians of any opportunity of deploying into fresh positions. More long ranging strategic considerations rendered it imperative to expedite the capture of the fortress. With the rainy season having descended upon the South African invading forces, Brink could brook no further impediments to the progress of the SAEC Road Construction Companies, who were building the road into the northern regions of Abyssinia and whose reconnaissance was being obstructed by the Italian occupation of Mega.

The rain commenced to fall once again at 09:00, rendering the roads impassable and thus the conveyance of supplies impossible. As a result the water ration was, paradoxically, reduced to one gallon per man per day for all purposes. At 07:00 C. Coy and its support sections moved off around the eastern corner of Dobbs Ridge, whilst the remainder of the battalion (minus B. Coy in reserve), under the command of $\mathrm{Lt}$ Col Dobbs, left Medaccio one hour later to rejoin C. Coy and supporting sections. This force ( $A$ and Support Coys) came under long range shell fire from Artillery Hill. The troops debussed and the motor transport returned to Medaccio. Lt Col Dobbs moved north along the eastern face of Dobbs Ridge with A. Coy, leaving Maj Morrogh to follow with the support weapons. The Colonel then moved up to a higher feature beyond Dobbs Ridge and at the summit of this position, at approximately 11:00, joined Maj Clare and C. Coy. It was decided that, under cover of machine gun fire directed at the enemy observation post on Mount Fornace ('Medical Tumour Hill'), an advance would be made to a higher ridge with A. Coy moving on the left flank of C. Coy. Majors Clare and Morrogh went forward with C. Coy and, after having been joined by A. Coy, they arrived near the bottom of the ridge which formed their next objective.

\section{The attack on 'Tumour Hill'}

Maj Clare now decided upon the elimination of the industrious observation post situated on 'Tumour Hill', which maintained telephone contact with various points in the Mega defences. A section of A. Coy was detailed to extirpate this Italian post. When this section commenced its attack, at 11:30 on 17 February, it was subjected to rifle fire from the crest and machine gun fire from the flank. The section commander, Cpl J.R. Kirk, kept his men continuously on the move, firing at the crest until dead ground was reached at the foot of the feature. He then led them up the cruelly steep slopes as they advanced. The supporting fire that had been planned to cover the assault did not materialize. Cpl Kirk made a determined advance, in the face of unknown odds, and the Bren gunner, Pte D.J. Callaghan, fired his gun from the shoulder as he went forward. The hill was captured, its defenders dislodged and the position consolidated. Approximately 30 minutes later this gallant section was attacked by some 40 of the enemy, who emerged from the bush close to the crest. This force was repulsed, leaving seven dead. Lt Col Dobbs comments upon this action thus:

'It was in my opinion a fine bit of work by the whole section, and, particularly on the parts of Cpl Kirk and Pte Callaghan.'

Cpl Kirk and Pte Callaghan were awarded the Military Medal (MM) in recognition of the gallantry displayed by them in this action [Callaghan's medal group is displayed at the SA National Museum of Military History, in an Exhibition devoted to the two South African Irish Regiments of World Wars I and II.] A vivid account of this episode is contained in the book Asbyssinian patchwork. The author is cited as being 'A South African Corporal', who served in 13 Platoon, C. Coy, commanded by Capt Cochran. He writes ${ }^{8}$ :

'The Major asked the men of "A" Company for twelve volunteers to blow it out. He then asked a platoon of 42 men, and all stepped forward. The Major said he only wanted twelve men, so he selected them, and together with a corporal they started off to climb the hill. They had twelve rifles and two Bren guns, and there was lots of cover on the hill. The enemy could see them coming and fired all the time, but they didn't fire back till they 
were in a good enough position, when they opened up. They fired for about ten minutes when the enemy stopped firing and put up a white flag.

The Major, being an old soldier, said "Don't get up". He got up himself. An Italian officer got up too. The Major called him over. (We could see all this from our hill). The Italian officer spoke to his men and we saw him pointing on the ground, so we thought he'd told them to ground arms and surrender, and then he suddenly dropped down and they opened fire again. So our Major, he said, "Next time they put up a white flag, let them have it."

Our men went on firing again, and up came the white flag again. So as soon as the Italian officer showed himself, they let him have it and he fell. Some of his men jumped up and started running away; a few were killed and the rest were taken prisoner.'

The above quoted account adds significantly to our knowledge of the SA Irish Regiment's participation in the capture of Mega in several respects. First, it allocates a prominent place to the Major who was in command. Neither Lt Col Dobbs nor the War Diary makes any reference to this field officer; whilst Neil Orpen's work does not include this episode. He was, presumably, Maj Ward Clare, who conceived of the attack. He is, moreover, the only field officer (apart from the $\mathrm{OC}$ and Maj Morrogh, the latter of whom was responsible for the support weapons) who is referred to in the primary sources. The problem of identification is exacerbated by the fact that the writer relates the death of Maj Ward Clare (once again unnamed) at an earlier point in his narrative (p. 103) (ie. prior to the attack on 'Tumour Hill'). Second, the overwhelming response to the call for volunteers evinces an extremely high degree of morale on the part of the Regiment; despite the appalling climatic conditions and resultant hardship that it was forced to endure.

\section{Land mines take their toll: death of Maj Ward Clare}

Simultaneously, C. Coy and the remainder of A. Coy continued towards their objective of the third ridge. However, they were soon confronted with an impassable road and thus compelled to move down the long bushy slopes towards the Mega road. Maj Clare seized this opportunity to endeavour to make contact with the left flank of 3 Bn Transvaal Scottish by crossing the Mega road. He undertook this task personally, as other agencies had failed. At this point more rain had fallen, and mist enveloped the hostile hills. The descent over the grass and slippery rocks was a wearisome experience, the men being soaked. As the tired troops approached the lowest point of the donga, a heavy explosion occurred; this being interpreted as shellfire, a general withdrawal ensued in the teeming rain. It was then discovered that Maj Ward Clare had detonated a land mine. It appeared to be one of several placed in that vicinity; presumably a trap for armoured cars that might seek a crossing after being delayed by the donga. This tragedy occurred at 12:15. Maj Clare died of his wounds two days later.

Lt Col Dobbs then moved down the hill and ordered $\mathrm{A}$. and $\mathrm{C}$. Coys to resume the advance. The troops now confronted a large amphitheatre, the southern spur extending down to the road, situated approximately half-a-mile ahead. C. Coy was to occupy the spur, whilst A. Coy was to take possession of the north-eastern heights, from which Mega could be seen at a distance of some $3 \mathrm{~km}$. As some of the troops were traversing the donga, Pte C.H. Wheeler was wounded by another land mine. The stretcher bearers ran back to render first aid and place Wheeler on a stretcher. As they moved off towards the Regimental Aid Post, Pte P.A. Zwanepoel trod on a land mine and was fatally wounded, whilst the injured man on the stretcher was killed instantly. The leading stretcher bearer, Pte L.P. Ryan, must have missed the mine by a mere few inches. He was merely thrown forward and only dazed.

A vivid account of these land mine explosions is contained in the work, Abyssinian patchwork:

'It was 12 when we got to the landmines. We were waiting for orders, standing under some trees to shelter from the rain, about fifty yards from a gully we had to cross, and one of our majors [ie. Ward Clare] and a sergeant walked down to have a look at it. The sergeant was called back, and the major went on alone, and as he went through the gully he put his foot on a land mine and the next thing we saw him go up in the air. The land mine smashed one of his legs badly, and two stretcher bearers ran down to pick him up. They carried him away to the C.C.S. [casualty clearing station] and then a machine gunner 
[Pte C.H. Wheeler] walked down the gully, and he went up in the air too. Then the two stretcher bearers ran down to pick him up, and both his legs were useless, so they asked him if he could crawl a bit closer, and he started crawling on his elbows, and the stretcher bearers couldn't bear that, so they ran forward, picked him up and put him a stretcher. They started walking back, and the back stretcher bearer [Pte P.A. Zwanepoel], he trod on a land mine, and the three of them went up in the air. The fellow already on the stretcher, he was killed outright. The other chap was just chucked away for 10 or 15 yards and he rolled over. Nothing seemed to be the matter with him but shock - he started running away, then came back and asked for assistance. One of our chaps - a fellow, who had been the company cook, went to help and picked up the stretcher bearer with the smashed legs and the machine gunner and put him on the stretcher. Then we were all afraid to go through the gully for fear of land mines, but Captain Cochran, he said he'd go through first and we'd walk in his footsteps. So we all got into single file and we tried to walk exactly in his footsteps. Aparently we did walk on land mines - the engineers found out afterwards, but the fuses were wet and they didn't go off.'

In the light of the two land mine explosions, and the toll that they had exacted, Capt Cochran's role in leading his troops through the mined areas is symptomatic of a high degree of courage.

\section{Misery endured for a second night}

Notwithstanding these tragedies, the prompt order to move forward again restored confidence, and the heights were occupied by 15:30, after the men had painfully ploughed their way through sodden black soil. At that point the rain had been pouring down for hours. The men, who had now been in action for two days, were exhausted from the cold and hunger, and it was accordingly decided to consolidate in the present position for the night. Lt Col Dobbs writes of the ensuing evening and night of 17/18 February as follows ${ }^{10}$ :

'The men who were up on the ridges overlooking Mega will never forget that evening and that night. Nearly everyone lost control of his jaws. Violent shivering is never a pleasant sight: when it grips a mass of men it is almost terrifying. Jaws were clattering with horrible machine like precision, and soon vigrous athletic youths were falling unconscious through hours of exposure to the bitter wind and the rain. Some of the men had to be unceremoniously undressed by their comrades and fiercely massaged as they stood naked on the storm-swept ridges.

All night transport struggled valiantly along the road, now reduced to a quagmire, evacuating about 35 of these casualties and bringing up food and blankets. When fuel could be found fires were lit, down in the amphitheatre, and soldiers numbed with cold staggered down from their defensive positions in the heights to enjoy warmth and hot food. Others were not so fortunate: the conditions were too appalling for adequate transport. [ Lt Col Dobbs is here referring to those troops stationed on remote hill positions]. At about 3 a.m. a brandy ration - a "swig" a man - was heartily welcomed.

Many of the men had no food for 36 hours. Fortunately most of the casualties were able to return in time for the toil and battle of the following day. It was mostly toil. At Mega, as elsewhere, natural obstacles were far more formidable than the fire of the enemy.

The hastily dug defensive posts on the southern spur of the amphitheatre provided a clear view of the village from the first light of the next day February 18th. The rain had stopped at last.'

The graphic account of that night furnished by the writer in Abyssinian patchwork casts a further illuminating light upon Capt Cochran's style of leadership ${ }^{11}$ :

'All that night it rained. We slept in the rain on the side of the hill and left a guard on top, and sent some reliefs every half hour. We made a bit of a fire on our side of the hill and, at about 2 a.m. one of our trucks did come through without lights. He yelled and we answered, "The Irish". He said, "I have water, blankets, groundsheets and some warm food..' We went down and brought up blankets, groundsheets, greatcoats. There were not quite enough to go round for all the men, so some still had to go without, and our Captain [ie. Capt Cochran] asked how many there were and found there were forty without, so he said, "If some of my men can go without, so can I."' 
Capture of Fort Hill (18 February 1941)

[cf Map 3]

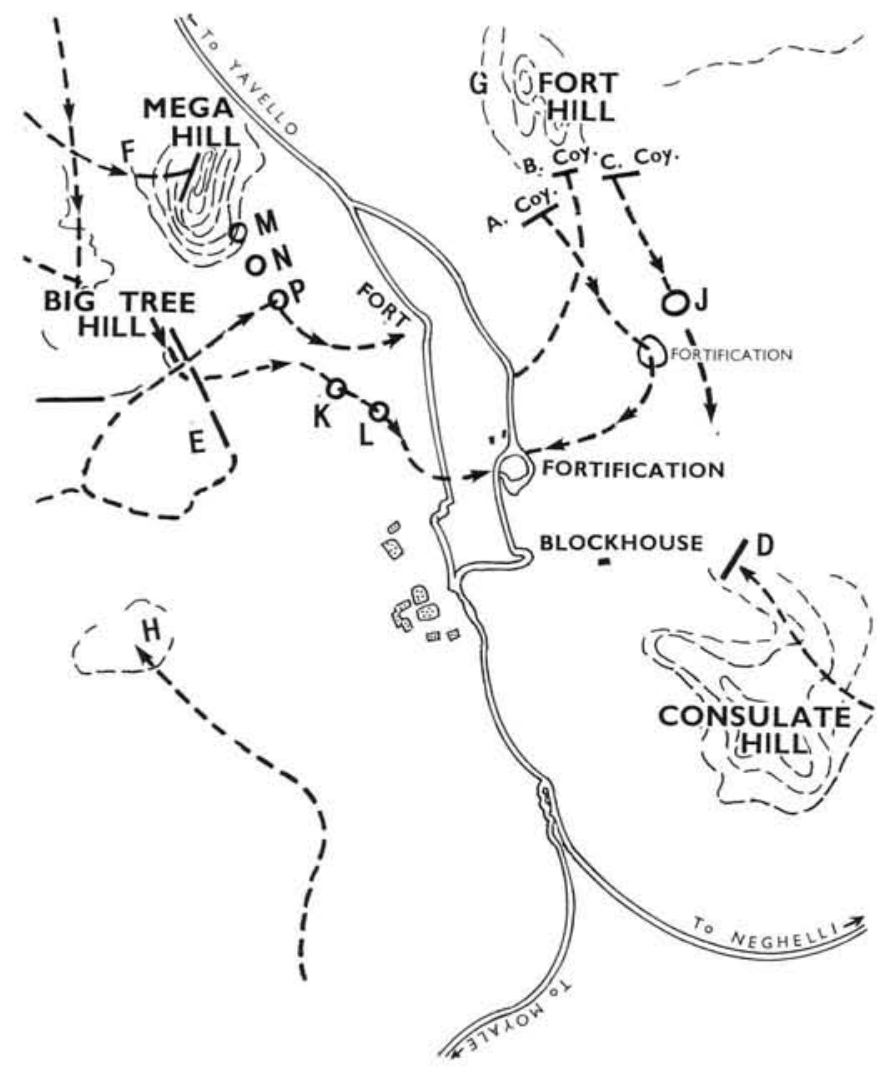

Dispositions of SA Forces, 18 February 1941 A Coy, B Coy, C Coy 1st SA Irish Regt, at 16:00, in
D

E

H

$J, K, L, M, N, P$ position for final assault A Coy, 2 Field Force Battalion, captured guns 16:50 A Coy, 3 Transvaal Scottish, 15:00 A Coy, 1 Field Force Battalion Gun emplacements C Coy, 3 Transvaal Scottish

Lt Col Dobbs describes the view of Mega, after the rain had ceased, on the following morning of 18 February, thus ${ }^{12}$ :

'Picturesquely set at the end of a broad, grassy plain almost encircled by hills, Mega's few red and white buildings two miles away looked pleasantly civilized. They were completely dominated, however, by an impressive fort that faced us in the foreground. It was a real Foreign Legion stronghold straight out of the pages of P.C. Wren, with loopholes and watch-towers and a great central gate: a fort that appealed strongly to the boy in every man. With their four howitzers on this feature, known to us as Fort Hill, hostile movement and machine gun posts could plainly be seen, amid the black bursting shell. The men were still wet, hungry and exhausted, but clothes that had been soaked for 36 hours soon became dry and the sight of our objective in the plains below was stimulating.'

At $08: 15 \mathrm{C}$ and $\mathrm{A}$ Companies moved on in the direction of the enemy observation post and machine gun positions on Fort Hill (Mount Gemelli), C Company returning from the spur on to the main line of ridges to join in the advance. The advance progressed over a ridge blanketed with almost impenetrable bush. Progress was slow and, for some time, contact between the two companies was broken. During the course of the morning the air force and artillery maintained a continual bombardment of both Fort Hill and any ponts on the Mega plain where enemy movement was seen or suspected. The artillery observation post was established on the ridge occupied during the night by A. Coy. The fort and village could be seen throughout the day in the valley below. At 14:00, under cover of machine gun and mortar fire, Fort Hill was finally occupied. The enemy, predictably, had evacuated the position prior to the assault. Lt Col Dobbs records the events leading to the capture of Fort Hill in his characteristically dramatic style (13):

'In the first stages of the advance the enemy ineffectively fired shrapnel and small high explosive into the wooded ridges. Their machine guns also came into action on Fort Hill. Cautiously we crossed the first donga, with land mines lying at the back of our thoughts, and then tackled the long ridge that faced Fort Hill. This was the worst piece of country we had met.

Ten feet high and almost impenetrable, the bush had to be conquered before the Italians. Officers and men fought and cut their way fiercely through, climbing all the time, often with only a vague sense of direction to guide them. Sharp branches yielded reluctantly to our battering bodies and then whipped back savagely to our faces, big boulders had to be surmounted, and breathless leaders had to keep contact with their men by constant shouting.

The whole dense mass of vegetation seemed to offer living resistance. No sooner had clinging thorns been cut away from our arms and equipment than others, equally wicked, appeared in their place. Almost in despair, men turned their backs to the bush to protect their heads and barged through a few feet at a time. This struggle lasted for hours. 
C and A Companies temporarily lost touch, but in such conditions it was ... creditable that platoons and sections kept contact. At last the conquered bush opened out into full sunlight at the top of the ridge and we saw the Air Force and Artillery bombarding Fort Hill, and the Transvaal Scottish, far away on the right of the road, ascending Mega Hill.

At 2 p.m. [14:00] the Irish forward rifle companies, under cover of a Vickers and Mortars barrage, climbed the steep bare convex slopes of Fort Hill. Two machine guns were found near the top. Beside one were the bodies of four soldiers of the 60th Colonial Infantry killed by a direct hit from a bomb or a shell. The enemy withdrew from this fort before our final assault, and "A" Company cleared the ridge and bush beyond it for about 300 yards.'

At 16:00 the entire battalion was re-united when B. Coy arrived at Fort Hill, after having left Medaccio shortly before noon. B. Coy remained in reserve.

\section{Final assault on Mega (18 February 1941) [cf Map 3]}

At 16:25 the final assault on Mega was launched. At 17:00 a bank of mist swept from the east over the ridge down which the Irish Regiment was advancing on Mega, penetrating the Mega valley, which completely disappeared from sight. Visibility was reduced to 100 yards. To the north, at 15:50, 9 Field Battery had moved its 4,5 inch guns forward to within 4000 yards of Mega to support the final assault of 5 SA Infantry Brigade, and the barrage commenced at 16:25. Direct hits were scored on the fortress by this battery, and the latter's guns soon advanced a further 1000 yards. The blankets of mist, which obscured the attacking infantry and thus entailed the danger of artillery firing upon the assaulting force, caused 9 Field Battery to cease firing at 16:55.

Fortuitously, we possess three eye-witness accounts of that final attack in the mist-blanketed valley, from the vantage point of the SA Irish Regiment. The first is furnished by the work, Abyssinian patchwork ${ }^{14}$ :

.... right in front there was another hill, on which was a blockhouse, and we advanced on that. There were four Breda guns firing at us. We'd good cover and, when we got the word to advance, we'd dash and land up behind some rock. Sometimes they fired rifles at us, but we did not fire back, because we couldn't see them. Our artillery was firing at the blockhouse.

We had two aircraft by then and they tried to blow up the blockhouse, but at first they were pretty wide of the mark. Then one plane went straight up in the air and dived, and we thought it was going to go right into the blockhouse, but instead he landed a bomb in the middle of it.

We crowded into the blockhouse to have a look at it. It was an awful sight. Head off one man. M.G.s [machine guns] all smashed up.

Soon after that we were sitting down under cover behind the ridge and every now and again we could just hear a shot go "ping" right in amongst us. One of our chappies - No. 1 Bren Gunner - called the Captain [ie. Capt Cochran] and said, "I think I see a movement in a tree", so he [ie. Capt Cochran] said, "Put a burst into it." He did, and we saw a chap come tumbling out, and that was the end of the sniper. We were then told to go on again, section by section, and given the order to fix bayonets, expecting a charge. We fixed bayonets. Our Vickers and mortars were covering us, but the guns had stopped for fear of hitting us. Then our section went over. I slipped and fell on my back and the rest of our boys came past thinking I was hit. I could see the expression on their faces, but I wasn't hit ... and, when I got up, I found everything was sprawled all over the shop. The enemy were firing, giving it stick; you could see the mud flying. After that we got stuck for a bit. No good cover, and a great big thing was firing things the size of a tennis ball at us for about half-an-hour.

The mist came up dark. You couldn't see a thing. In the end it started clearing and, as it cleared towards the Italians we advanced... I remember we were told to be very cautious in case of [booby] traps. Then suddenly the mist cleared and we saw the fort and the flag coming down off the fort and all the enemy coming out surrendering. [This occurred at 17:30.] They came with big white flags, and they came without arms or anything, but we got down and lay ready with our rifles in case of monkey tricks... 
I must say the Italians are masters at camouflage - you had to be right on top of a place before you recognized it... Only in one place did we find one of the enemy. He crawled out with tears rolling down his eyes, and he whipped out a photo and said, "Wife, wife." We said, "Did you see us coming up the hill?" He shook with fright and said he had seen us crawl a little yes. He said, "Are you going to kill me?" and we said, "No."'

The second eye-witness account is the oral testimony of Lt Col Cochran*, who stated that:

'We could only see a few hundred yards ahead. We realized that we were getting pretty close to Mega and on the top of the hill was a little blockhouse. I was pretty sure that this was a machine-gun post so we made our way very cautiously up this and the last that I remember of that particular scene was throwing a hand grenade into this place. The first one that I threw fell short and began to roll backwards towards me which gave me a little bit of a start. That exploded but I escaped any injuries from the blast. Then the two occupants of the blockhouse came out with their hands up and we collected them. After this it was all downhill into Mega. As we were running towards Mega - pursuing a zig-zag path to avoid machine gun fire - I was hit in the leg and bowled over. Fortunately my CSM was very close to me and he managed to get a couple of fellows to carry me down on a stretcher, in which I was carried into Mega fort. The Transvaal Scottish had come round on the other side and they had entered Mega first.'

The third personal narrative is contained in the memoirs of Mr West, who writes ${ }^{15}$.

'Once again we were advancing under cover of our mortars and I was glad to be a rifleman. as those mortars were very heavy. Carrying them uphill in the mud could not have been easy.

We came under very heavy machine gun fire and had to take cover behind a ridge. It was still raining and I pulled my groundsheet over me as best I could...

The machine gun was finally silenced and we

${ }^{*}$ Communicated to one of the authors, S. Monick (10 August 1987). were given the order to advance over the ridge. In front it was absolutely flat and I was able to see where the machine gun had been situated, in a concrete pill-box. We learned later that Col Dobbs had been present when the black gunner surrendered, that he had given the [Colonel] some cheek and Capt Power, in the process of administering a kick to his rear, had slipped in the mud and landed on his own rear

The next I remember is being met by $\mathrm{Col}$ Dobbs in a clearing, and being ordered to form line. We formed up facing him only to be told: "Not that kind of line". He wanted us in single file behind him and while facing him we were ordered to fix bayonets. This was my biggest dread - a bayonet charge, and I must have given him some indication, because when I looked up I saw Col Dobbs smiling and I felt sure he was looking at me. He then ordered us to follow a footpath down the ridge in single file. I was behind Corporal Lovemore and remember his rifle going off as the trigger snagged a bush. At that moment I thought we were coming under fire again, but after proceeding for a while we saw the village ahead. We were ordered to search the houses for occupants.

Every house I went to was empty and it was soon evident that the village was deserted. I remember looking for Italian wine without any luck. Eric Morrow however managed to locate a bottle which he refused to share. He was going to drink it all himself that night, and no pleading had any effect. He was acting as company runner and this was his reward.

Shortly after this the Italians set fire to their ammunition dump on my left. It was like a fireworks display except that bullets and shrapnel were flying around uncomfortably close at times. It was about this time that I came upon Pipey Symons and some other members of the Band who acted as stretcher bearers, lifting one of our men onto a stretcher. He had trodden on a mine and his leg was blown off, including his private parts. He was fully conscious and felt no pain and was under the impression that he had a minor wound, which would take him back to the Union, and he was boasting that he would soon be with his wife, whom he had married while on embarkation leave. Drummer [Zwanepoel] died that night. [It should be noted that the official records cite Pte Zwanepoel's 
death as occurring on 17 February 1941; ie. the preceding day.]

It was getting dark and I could see the fort ahead. It was with relief that I recognized some of B Company outside the walls. I also saw Eric Morrow with his bottle. We were informed that we were not allowed to sleep inside the fort and had to sleep outside. We were all very tired and wet and hungry and thirsty and cold and not in the best of humour, but managed to find enough wood to make a large fire. Eric Morrow opened his bottle which he had been carrying around all day and took a large swig, in front of me, only to spit the lot into the fire which immediately flared up. He was fortunate that he had not swallowed [any] because he had been carrying around a bottle of paraffin, much to my amusement. Eric never lived this down...

.... we heard that Col Dobbs, after being presented [with the sword of the] Italian commanding officer, had thrown it on the ground in an insulting manner. That sword was never found.'

In the course of the descent upon the Mega valley, Pte P.J. Harle was mortally wounded (dying on 23 February).

The above quoted three sources, reflecting the experience of the attack upon the Mega valley from three individualized, impressionistic angles, reinforce one another in creating a detailed record of the events. None can be totally comprehensive, in the light of their individual vantage points, but, combined, they contribute to the complete mosaic. Thus, the account of the writer in Abyssinian patchwork is greatly enriched by Lt Col Cochran's recollection of the attack upon the blockhouse (including the graphic incident of the misadventure of the hand grenade). The latter's narrative excludes, however, the evocation of the pathetic Italian prisoner and the gruesome remains discovered in the bombed block house. With reference to the former observation, regarding the abject capitulation of the Italian defenders, this point is strongly reinforced by Pte Liversage, who writes in his memoirs, on p. $7^{\star}$ :

\section{'... by afternoon of the third day, when we}

\footnotetext{
*Englander, for you the war is over. Unpub. TS.
}

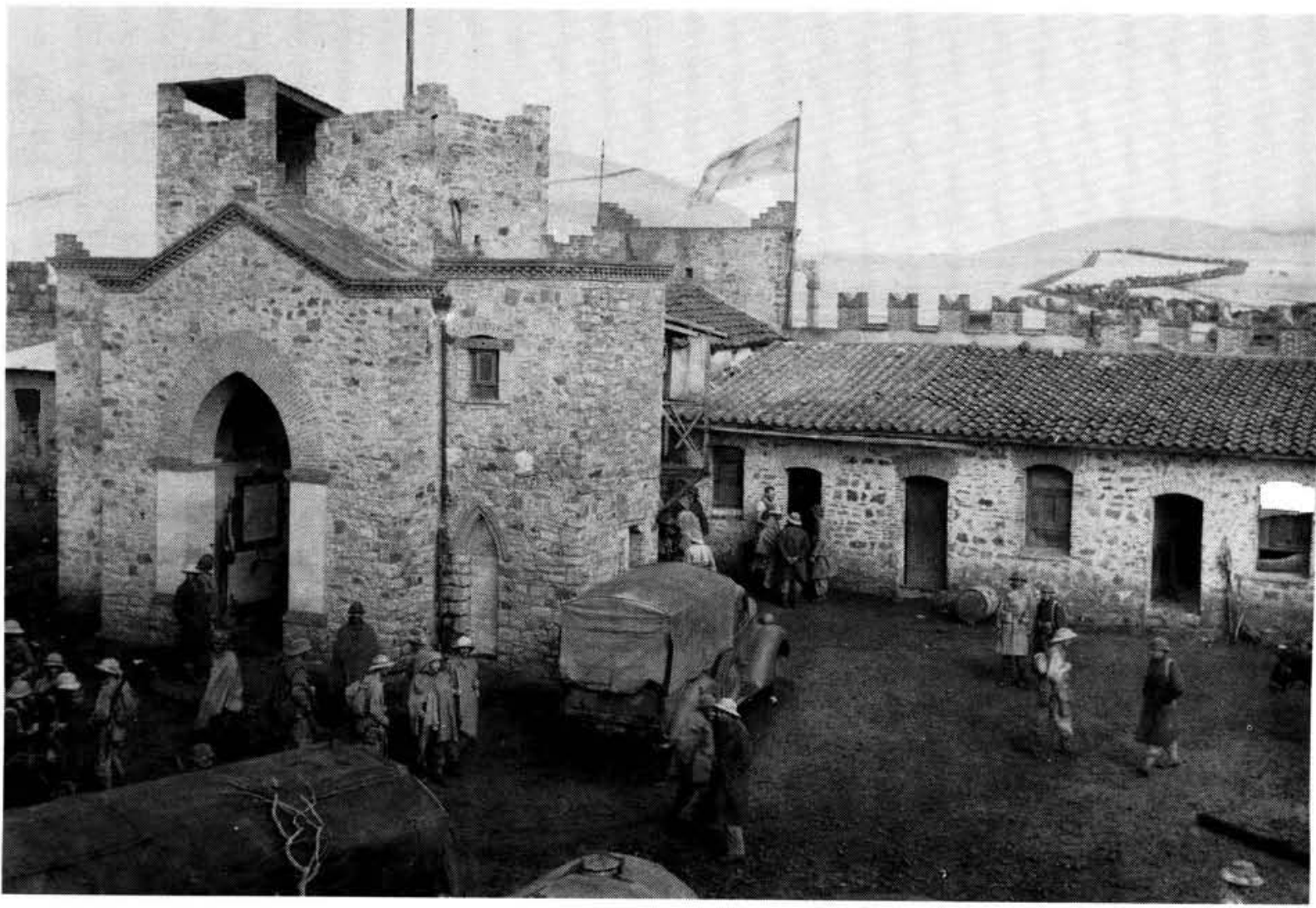

Interior of Mega Fort, after occupation by South African Forces 
went in for the final assault with fixed bayonets, we were in a rather vicious frame of mind but this mood quickly dissipated on meeting the Italians and they quickly surrendered in large numbers; in fact some even disgusted us when they tried to kiss our boots.'

The account furnished by Mr West ${ }^{16}$ includes an interesting encounter with Lt Col Dobbs. The former graphically evokes the image of a battlehardened soldier with an utter contempt for danger (indeed, one who positively relished the hazards of the battlefield). The reference to Dobb's insulting attitude to the Italian Commander's offer of the latter's sword is noteworthy. Did the former's attitude emanate from contempt for the character of the Italian defenders, or from anger at the losses which his battalion had sustained in the course of the assault? Mr West further enriches our visualization of the scene by the touching portrayal of Pte Zwanepoel immediately prior to the latter's death. The pathos of such situations is invariably omitted by the cold, depersonalized records of the official histories (as well as by the vast majority of regimental historians). The details regarding the mistaken bottle of paraffin might well appear irrelevant, but for the fact that the juxtaposition of this incident with the description of the dying Zwanepoel impresses the reader with the coincidental manifestation of farce and tragedy, which so frequently characterizes the battle scenario.

\section{EPILOGUE TO MEGA}

The Italians sustained losses, in the course of the South African capture of Mega, of 12 killed (one officer and 11 other ranks, and 14 other ranks wounded.) The prisoners consisted of 23 officers (including a Colonel), 570 European soldiers and 344 natives. The equipment captured comprised 53 machine guns, three field guns, four obsolete $120 \mathrm{~mm}$ Creusot guns and 580 rifles, in addition to quantities of ammunition, stores and vehicles.

Fires were lit in the fort and food cooked, but some of the men had to lie in large, roofless rooms and so endured their third successive night of exposure to the rain.

On 19 February Maj Ward Clare was laid to rest, and Lt Col Dobbs recorded the event as follows ${ }^{17}$ :

'There was a sad procession on the morning of the 19th up onto the lower ridge of Mega Hill, when the body of Major A. Ward Clare was buried with full military honours. His grave overlooks the picturesque fort, the quiet encircling hills that may never again echo with the noise of battle, and the scenes of the final assault in which he would have been happy to take part. His brave spirit still seemed to be near us on that sunny morning as a Scottish piper played a lament. The Regiment will remember him.

A requiem for Maj Ward Clare was held in the fort chapel on the morning of 24 February. The OC pays a further tribute to Maj Clare when he describes him as 'a fine officer, as popular as he was efficient.'

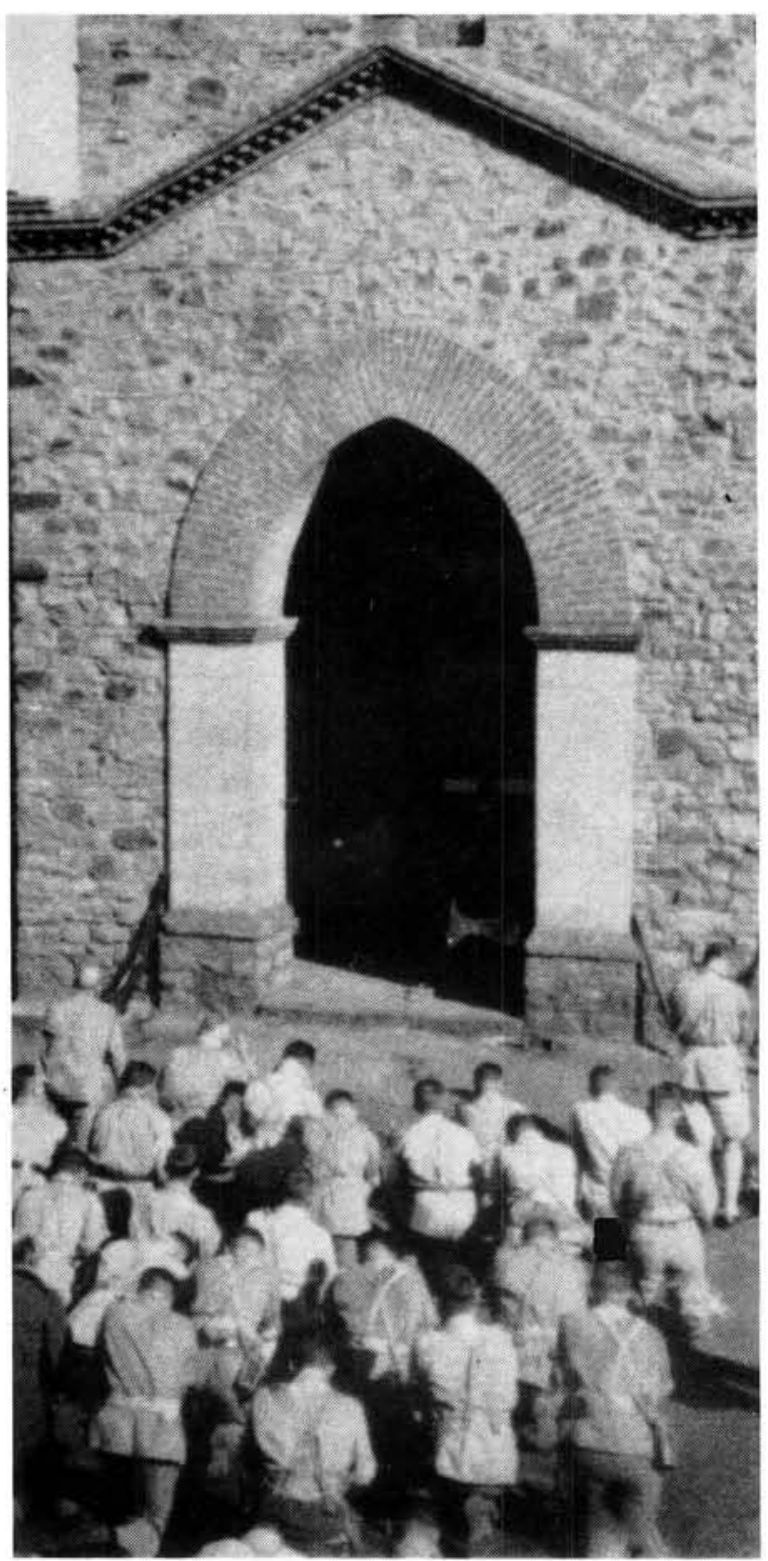

Funeral of Major Ward Clare, outside walls of Mega Fort 
On 23 February Pte P.W. Roos died from the effects of an accidental wound in the arm. Immediately after the capture of the fort, the SA Irish almost incurred another fatal casualty, as Mr West relates in his memoirs ${ }^{18}$.

... we were taken to a place outside the perimeter and out of sight of the fort and told to prepare camp. We were there long enough for some chaps to go out and shoot a huge kudu with a captured Italian rifle. I mention this because the bolt blew back and nearly killed the marksman as well. We were very chary of [Italian] rifles after that.'

In the ensuing fortnight the SA Irish Regiment was involved in garrison duties at Mega. The Battalion held a large sector of the Mega defences between the fort and Dobbs Ridge. On 24 February a platoon of C. Coy patrolled $53 \mathrm{~km}$ of the Yavello road, and a Fiat lorry was found. Neither this patrol nor one from B. Coy, which traversed the same ground two days later, saw any signs of the enemy.

On 28 February the Battalion was notified of the appointment of Maj W.J. Morrogh, MC, as the successor of Maj Ward Clare as second-in-command. Capt Cochran's services at Mega were recognized by the award of the Military Cross (MC).

On 5 March the Batallion left Mega for Wajir, in very unsettled weather, crossing the Kenya border at the ill-starred fort of Moyale; thus ending the Regiment's brief, but memorable, campaign service in Abyssinia. The SA Irish Regiment's withdrawal from the Abyssinian theatre prior to the final conquest of the territory parallels the situation of its predecessor in South West Africa in 1915. It represented part of the re-deployment of both 2 and 5 SA Infantry Brigades. Gen Cunningham had ordered an immediate re-distribution of South Afican forces prior to 4 March 1941. This re-deployment involved 21 East African Brigade being transferred to the Mega-Moyale sector, in order to permit 2 Brigade to withdraw into Marsabit and 5 Brigade to Wajir.

\section{CONCLUDING OBSERVATIONS ON SA IRISH REGIMENT'S SERVICE IN ABYSSINIA}

\section{Challenging military environment}

As Lt Col Dobbs states in his account of Mega, the enemy confronted by his battalion, in com- mon with the other units with which it was brigaded, and also 2 SA Infantry Brigade, consisted in the main of natural obstacles and not the Italian forces. The barriers presented by the former offered considerably greater resistance than the latter. The two principal actions in which the Irish Regiment was involved - Banno (8-9 February 1941) and Mega - were dominated by extremely inhospitable mountainous terrain, which had to be scaled. The capture of Mega was, in addition, attended by the most appalling climatic conditions, the troops being exposed to heavy rain for some 36 hours, without protective clothing of any kind and suffering from an extreme dearth of provisions as the result of the virtually impassable roads. The arduous environment was embodied in the final assault upon Mega, prefaced by the extremely tortuous ascent for Fort Hill (in admittedly clear, dry weather), succeeded by the running descent into the Mega valley, which was subject to the fluctuating climate, the valley being shrouded in mist in the course of this final assault.

\section{Roots of a firm military tradition}

It may be argued that the physical barriers thus surmounted were metaphorical conquests in the collective psychological landscape of the Regiment. The SA Irish Regiment was confronted with very real challenges, unlike the debilitating experience of South West Africa in World War I. The undoubted success of its response to these challenges was acknowledged in the increasingly prominent role allocated to the Battalion in the course of its participation in the Abyssinian campaign (more specifically, in the El GumuHobok-Mega sector, the occupation of which outflanked Moyale). Thus, in the action at Banno, the SA Irish Regiment formed the main infantry component of the assaulting force; whilst at Mega the Battalion played a major role in the subjugation of the Italian forces (including the elimination of the important observation post on Mount Fornaco, the traversing of the mined approaches, and the attack on the blockhouses during the climax of the offensive.)

Such endeavours were crucial in forming a firm base of military tradition which, to reiterate, South West Africa had signally failed to provide in the Great War of 1914-1918. The establishment of such a foundation was critical in the case of a volunteer battalion lacking roots in the South African military establishment. The Regiment's ability to transcend the disabilities of a war service battalion, and establish a permanent 
position in the post-war UDF, may be attributed in a certain measure to the unifying power of this military tradition, firmly anchored in the Abyssinian campaign

\section{Role of the officer establishment}

The leadership provided by the officer cadre was an instrumental factor in this process. Within this context, due acknowledgement must be made to Lt Col Dobbs. Although a far from popular and approachable figure, it has to be admitted that his personality made a deep impression upon those who served under him, and he fully realized the vital necessity of combat experience in welding his battalion into a psychologically unified military entity. Significantly, in relating his experiences of Banno, Mr West writes in his memoirs ${ }^{19}$.

'I am proud to have been a member of Dobbs force',

The role of Maj Ward Clare in the inspiriting leadership afforded by the officer establishment was a further highly significant factor. One gains the inescapable impression that, as second-incommand, he did much to bridge the social and psychological distance between the officer establishment and the rank and file. Mr West's clear recollection of Maj Ward Clare's comments at Marsabit (cf above) lends strong credence to this hypothesis. A further tribute to Maj Ward Clare is contained in an article by RSM A.H. Brehem, published in Die Laevelder en Barberton Nuus, dated 19 March 1971 and entitled The First South African Irish Regiment 1939-1945. RSM Brehem writes:

'At Mega the Irish lost a great soldier and a wonderful man - one could say the "father of the Irish Regiment" - Major Ward Clare.

Significantly, RSM, Brehem describes Maj Ward Clare within the context of a paternal connotation.

The courage and inspired leadership of Capt Cochran, whose company (C. Coy) played a prominent role from the outset of the Mega offensive, was a further most important contribu-

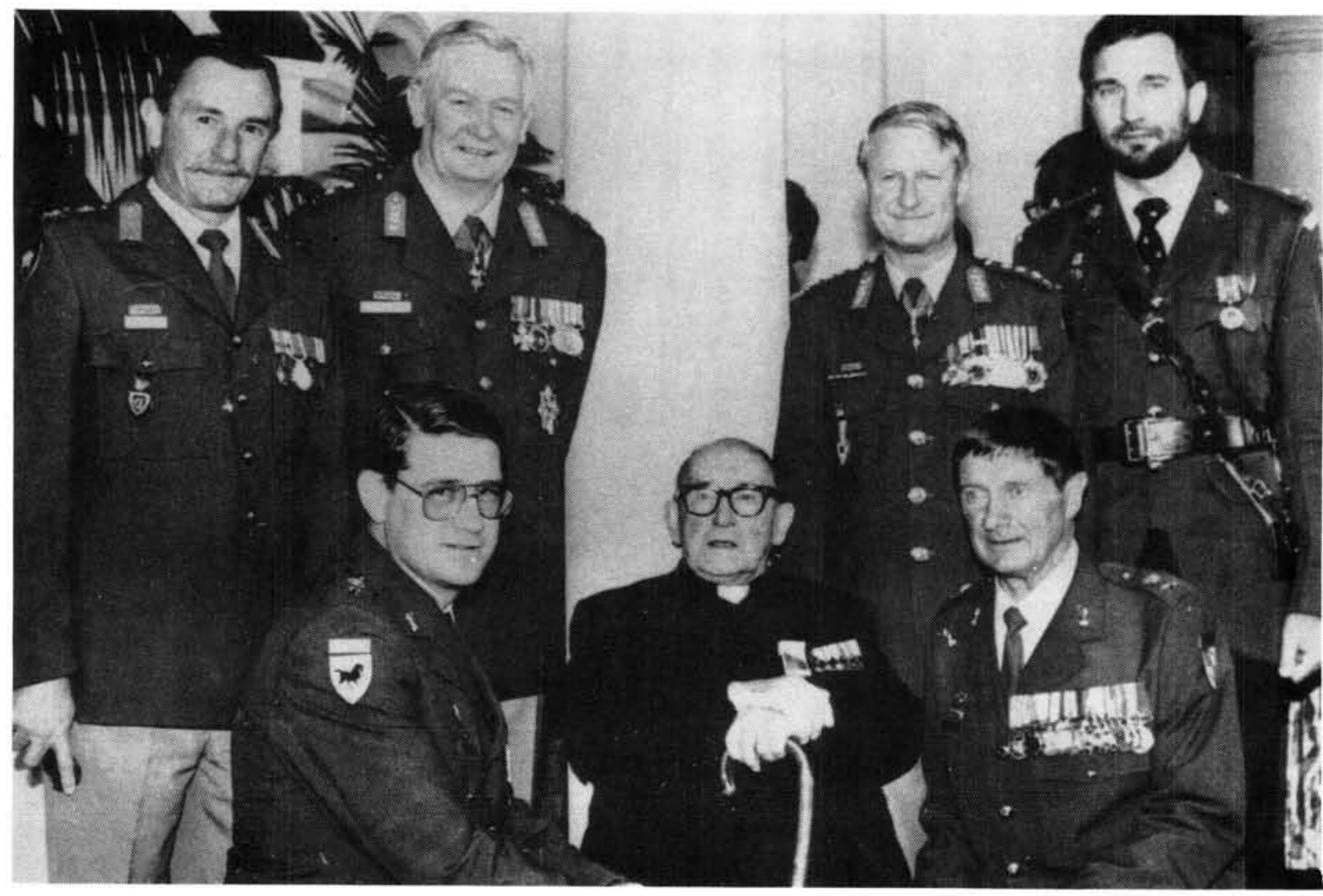

Fr Nolan at investiture ceremony, when he was formally presented with Order of the Star of South Africa (non military) (Class IV: Officer)

Front row (seated)(left to right): Cmdt G.J. Eiles, Maj (Fr) P. Nolan, Cmdt O.E.F. Baker.

Two former OCs of the S.A. Irish are to be seen in this photograph; Brig J. Bosch (far left) and Cmdt A. Karlz (far right), standing with Lt-Gen I.R. Gleeson (2nd left) and Gen Jannie Geldenhuys 
tory factor to this psychological symbiosis. This aspect is clearly embodied in the tribute paid to him by Lt Col Dobbs, in the OC's report of the Mega operations ${ }^{20}$ :

I would like to make special mention of the work of Capt C. McN. Cochran, Commanding "C." Coy, during the 3 days operations leading to the capture of Mega. His Company, which with 3 Secs [sections] of Support Coy, attached, was the only one in my sector which took part in the first day's operations, began to feel the effects of lack of food and exposure next morning, for it had rained hard that day and night. Through the second and third days he led his Company on over difficult hilly and sodden ground, with rain pouring down and the second night was spent on top of a bare hill in the cold and rain and with inadequate food.

In spite of these hardships, the Company worked forward and it was chiefly due to his inspiring example of courage and perserverance that the objective was reached. Capt Cochran was shot through the leg while leading his Company in the final assault.'

The role of the seasoned Warrant Officer/NCO establishment was a critical factor in this annealing, or tempering, of the Regiment afforded by the Abyssinian experience; as also was the con- sistent moral guidance and strength furnished by the padre, Fr Nolan.

${ }^{\star}$ Dr Monick (PhD) is attached to the S.A. National Museum of Military History.

Cmdt O.E.F. ('Ossie') Baker, DWD (\& Bar) recently retired from the S.A. National Museum of Military History, where he was engaged as Public Relations Officer and Curator of Ordnance.

\section{Bibliography}

1. Conversation between one of the authors (S. Monick) and $\mathrm{Lt} \mathrm{Col}$ Cochran: 10 August 1987.

2. Conversation with Mr R. ('Dick) West, in conjunction with Mr J. Schultz: 4 April 1990.

3. Conversation between one of the authors (S. Monick) and Maj (Fr) P Nolan: 4 May 1989.

4. West, R. To be a man. Unpub TS, 1988, p. 4.

5. Orpen, N. East African and Abyssinian Campaigns. Cape Town, Johannesburg: Purnell, 1968. p. 8. (South African Forces in World War II. Vol. 1.).

6. Dobbs, J.F.K. The South African Irish: Abyssinia. Unpub TS, p. 8.

7. Dower, K.G. (comp). Abyssinian patchwork: an anthology. London: Frederick Muller, 1949, pp. 102-103.

8. Ibid item 7 above, p. 104

9. Ibid item 7 above, p. 103

10. Ibid item 6 above, p. 9 .

11. Ibid item 7 above,p. 105.

12. Ibid item 6 above.

13. Ibid item 6 above, p. 10

14. Ibid item 7 above, pp. $105-106$

15. Ibid item 4 above, pp. $29-30$.

16. Ibid item 4 above, pp. $29-30$.

17. Ibid item 6 above, p. 11 .

18. Ibid item 4 above, p. 30 .

19. Ibid item 4 above, p. 24 .

20. Ibid item 6 above: Annexure. 